\title{
Implications of COVID-19 labour market shocks for inequality in financial wellbeing
}

\author{
Ferdi Botha $^{1,2}$ (D) John P. de New ${ }^{1,2,3}$ (D) - Sonja C. de New ${ }^{2,4,5,6}$ (D) \\ David C. Ribar ${ }^{1,6,7}$ (D) Nicolás Salamanca ${ }^{1,2,6}$
}

Published online: 4 January 2021

(C) The Author(s), under exclusive licence to Springer-Verlag GmbH, DE part of Springer Nature 2021

\begin{abstract}
Australia's economy abruptly entered into a recession due to the COVID-19 pandemic of 2020. Related labour market shocks on Australian residents have been substantial due to business closures and social distancing restrictions. Government measures are in place to reduce flow-on effects to people's financial situations, but the extent to which Australian residents suffering these shocks experience lower levels of financial wellbeing, including associated implications for inequality, is unknown. Using novel data we collected from 2078 Australian residents during April to July 2020, we show that experiencing a labour market shock during the pandemic is associated with a $29 \%$ lower level of perceived financial wellbeing, on average. Unconditional quantile regressions indicate that lower levels of financial wellbeing are present across the entire distribution, except at the very top. Distribution analyses indicate that the labour market shocks are also associated with higher levels of inequality in financial wellbeing. Financial counselling and support targeted at people who experience labour market shocks could help them to manage financial commitments and regain financial control during periods of economic uncertainty.
\end{abstract}

Keywords Financial wellbeing · COVID-19 · Unemployment · Earnings reduction · Inequality

JEL classification D14 $\cdot \mathrm{D} 31 \cdot \mathrm{J} 65$

Responsible Editor: Klaus F. Zimmermann

John P. de New

johnhd@unimelb.edu.au

Extended author information available on the last page of the article 


\section{Introduction}

The COVID-19 pandemic has spawned a substantial international health and economic crisis. Nations racing to slow the spread of the virus have imposed lockdowns and social distancing measures (Qiu et al. 2020; Bonacini et al. 2021), which have shuttered businesses, forced people out of work, and decimated incomes. The World Bank (2020) projects that the global economy will contract by $5.2 \%$ in 2020 , experiencing "the deepest global recession in eight decades, despite unprecedented policy support." While aspects of the macroeconomic consequences have been carefully considered (Milani 2021), we know much less about the extent to which the crisis is affecting individuals' financial wellbeing or how people are coping financially. Job and earnings losses are undoubtedly harmful to financial wellbeing, but the size of the impacts is uncertain because myriad factors, including people's financial reserves and financial behaviour, ability to shift expenses, government assistance, and social resources, provide ways of mitigating the effects.

In this paper, we investigate how labour market shocks, as a direct result of the implemented social distancing and lockdown measures during the COVID-19 pandemic, are associated with the perceived financial wellbeing ${ }^{1}$ of people living in Australia. We are specifically interested in the relationship with financial wellbeing, rather than income alone. Financial wellbeing can range widely within income levels and is arguably a more direct measure of people's enjoyment of their income, their consumption, and their financial worries and constraints. In comparison to focusing on income, financial wellbeing gives us a holistic view of the true pressures felt by all individuals across the income and wealth distribution during the pandemic.

Financial wellbeing as a validated multi-item empirical measure is a relatively new development. Our measure is defined in terms of the extent to which individuals feel that they are able to meet their financial obligations, have the financial freedom to enjoy additional consumption and other fulfilling choices, control rather than be controlled by their finances, and have security and be free from financial anxiety now, in the future, and under possible adverse circumstances. Our validated measure captures functional, situational, and temporal components, and while it is related to objective financial indicators, it is a distinct concept, as shown in Comerton-Forde et al. (2018, 2020). It is positively correlated with income but distinct in that it is a multi-faceted measure that captures key elements such as uncertainty and future security, which income would miss. It is also superior to single-item financial satisfaction measures, which are loosely framed and not expressed in terms of specific financial outcomes, thereby making comparisons across groups very difficult. Our chosen financial wellbeing measure has been rigorously tested and validated, in contrast to most other existing financial wellbeing measures. ${ }^{2}$

As one of the first studies of its kind, we use unique survey data collected during the intense period of the coronavirus pandemic in Australia between April 20 and July 7

\footnotetext{
${ }^{1}$ The instrument used in this paper to measure financial wellbeing is based on individuals' perceived, or selfreported, levels of financial wellbeing. Within the context of this paper, when referring to "financial wellbeing", we are referring to perceived financial wellbeing and not based on objective indicators such as savings balances.

${ }^{2}$ See Comerton-Forde et al. (2020) for a thorough review of the existing literature, and Botha et al. (2020b) for more details on the construction and validation of our financial wellbeing measure.
} 
2020. The survey contained the validated financial wellbeing scale as well as a set of demographic information, and in particular questions around individuals' labour market experience during the pandemic. This allows us to study people's financial wellbeing associated with labour market shocks following from COVID-19 restrictions in Australia.

A range of studies have been conducted on how COVID-19 has affected different outcomes. For example, Brodeur et al. (2020) explored the relationship to mental health; Fetzer et al. (2020) looked at changes in economic anxiety; Belot et al. (2020) considered the wealth implications of the pandemic; Botha and de New (2020) examine the relationship to (Likert 0-10 scale) life satisfaction and its satisfaction subdomains: health, family life, family health, health services, and finances. The study most relevant to this paper is Biddle et al. (2020a, b), which also used Australian survey data. Using ANUpoll data from April 14 to 27, 2020 and comparing those responses to the same individuals interviewed in the ANUpoll in January and February 2020 (Biddle et al. 2020a) and later in August 2020 (Biddle et al. 2020b), the researchers considered the relationship of COVID-19 to factors such as employment, labour supply, life satisfaction, income, financial distress, and mental health. Our study differs from Biddle et al. (2020a, b) in that we examine specifically financial wellbeing as an outcome and its association with COVID-19-related labour market shocks. Our paper also contributes to the other existing literature on COVID-19 mentioned previously by being the first to investigate how individual perceived financial wellbeing is associated with COVID-19 labour market shocks.

We conceptualise the determinants of financial wellbeing through a rational-choice lifecycle framework in which people make current financial decisions, including spending, bill-paying, saving, borrowing, investing, and insuring, to maximise their current and expected future utility. In each period of their lives, people have economic resources that come from their earnings, investment income, wealth, and other sources and that give them scope to undertake financial behaviours. Previous financial behaviours, such as saving or borrowing, add to or diminish the current set of resources. Similarly, current financial behaviours affect future resources and opportunities. For working-age people, current and expected future earnings are a key resource for producing financial wellbeing.

In this framework, negative involuntary labour market shocks, such as unemployment, reduced work hours, and lower wages, are expected to be related to financial wellbeing through several channels. First, negative labour market outcomes reduce current and permanent income, and thus decrease the resources that are available to achieve financial wellbeing. Previous research has found that higher levels of income and wealth are associated with greater financial satisfaction (Bonke and Browning 2009; Brown and Gray 2016), fewer financial hardships (Shim et al. 2009), and increased financial wellbeing (Comerton-Forde et al. 2020). Second, negative labour market shocks could reduce people's credit ratings and borrowing ability, which would reduce the scope for financial behaviour and impact financial wellbeing (French 2018). Third, shocks would increase the volatility and uncertainty of people's resources and make their finances more difficult to manage. Fourth, labour market shocks could have adverse psychological effects (Biddle et al. 2020a), which might influence financial wellbeing, such as through loss of control (Vlaev and Elliott 2014) and increased stress 
related to money management as well as increased feelings of expected financial insecurity in the future (Netemeyer et al. 2018).

Consistent with these mechanisms, research has found direct associations between unemployment and several financial outcomes, including financial satisfaction (Bonke and Browning 2009; Brown and Gray 2016; Simona-Moussa and Ravazzini 2019), difficulties managing financially (French 2018), and financial hardships (Scutella and Wooden 2004). Only two studies have investigated the effects of adverse labour market outcomes using comprehensive, summative measures of financial wellbeing. Brenner et al. (2020) found a negative association between unemployment and the U.S. Consumer Finance Protection Bureau (CFPB) scale of financial wellbeing (CFPB 2017), and Comerton-Forde et al. (2020) found a similar relationship using the Melbourne Institute-Commonwealth Bank of Australia Reported Financial Wellbeing Scale (Comerton-Forde et al. 2018). However, both of these studies examined joblessness in the context of a robust economy and not in the midst of a global crisis.

Our study finds that labour market shocks directly related to COVID-19 are associated with substantial and significant declines in financial wellbeing, not just on average, but in particular at the lower end of the financial wellbeing distribution. Distribution regressions suggest large potential gains in financial wellbeing equality if one were to remove counterfactually the negative associations of COVID-19 labour market shocks across the financial wellbeing distribution.

Our findings provide a first measure of the significant negative relationship between labour market shocks triggered by the COVID-19 crisis and financial wellbeing. More than just affecting people's employment and incomes, the COVID-19 economic shocks are associated with people's ability to enjoy their financial freedom, their consumption, their financial security and stability, and their tranquillity about future outcomes. Perhaps more importantly, we show these labour market shocks are disproportionately felt by people at the lower end of the financial wellbeing distribution. Our results thus contribute to a growing international literature documenting the nature of the COVID19 crisis across societal outcomes and complements existing evidence on its generally (but not universally) regressive associations with employment, income, and industrial activity.

In the Australian context, much has been and is being done by the government to stave off the worst of the economic downfall, and there are several targeted labour market programs. However, as we find negative associations between the labour market shocks and financial wellbeing in a high-income country such as Australia with significant temporary government transfers during the pandemic, it seems that bolstering income alone might not be sufficient, as it likely cannot eliminate the uncertainties felt by individuals about their future financial situations and the pressures related to having to adjust spending and wealth portfolios to cope with new financial pressures now and in the future. Financial outreach programs targeted at individuals experiencing a labour market shock during the pandemic to help manage their finances during the crisis could have large returns in improving financial wellbeing, especially at the lower end of the distribution. 


\section{The Australian context and experience}

Between March 10 and July 30, 2020, Australia recorded 16,303 recorded coronavirus infections and 189 deaths. At its first peak on March 28, Australia recorded 458 new infections. Later in the second peak on July 30, daily new infections reached 721 . The Australian labour market was profoundly hit by the imposed measures to restrict the outbreak. Starting on March 23, around the peak of the first wave of the coronavirus crisis in Australia, non-essential businesses, including bars, cinemas, religious facilities, casinos, and gyms, were closed. Several days later many shops began to close and stand down staff. The demand for welfare payments rose so quickly that the website of the Australian government agency responsible for welfare payments, Centrelink, crashed. In the following days, starting March 26, further businesses were mandated to close: restaurants, cafes, and food courts. A second wave of COVID-19 infections started at the end of June affecting the state of Victoria only. As such by July 30, 2020, Victoria installed dramatic state-wide emergency plans mandating that people stay at home unless going to get medical help, getting supplies, going to a workplace where the work could not be done at home, and caregiving.

The various impacts on Australian businesses are reflected in the official labour market statistics in Appendix Fig. 4. The unemployment rate increased by $2.2 \%$ points from $5.2 \%$ in March to $7.4 \%$ in June. The government introduced a wage subsidy (JobKeeper), which kept people officially in employment, albeit with significant reductions in wages and hours worked. If we group these underemployed individuals, who would prefer to work more hours than are currently available to them, together with the unemployed, this underutilisation rate is much higher at $19.1 \%$ in June. The demand for welfare benefit payments as proxied by the Google search frequency for Centrelink increased by $213 \%$ between February and March 2020.

\section{The COVID-19 and YOUR Wellbeing Survey}

The data for our analyses were collected from April 20 to July 7, 2020 using a customised Qualtrics survey, COVID-19 and YOUR Wellbeing. ${ }^{3}$ In addition to very basic socio-demographic indicators, the survey asked about many outcomes relevant to the crisis, including personal events experienced due to COVID-19, financial wellbeing, subjective wellbeing, and mental health (24 question blocks in total). Respondents could opt out of the survey at any time, and their responses up to that point in time would be recorded. Respondents always had the option to respond "prefer not to say".

A combination of snowball sampling and targeted advertisement on social media was used to recruit participants. The link to the survey was shared on Twitter and Facebook by the researchers. A Facebook page was created with information on the study and link to the survey. Facebook advertisements were run weekly between April 28 and July 7, 2020. The advertisements were targeted at people living in Australia,

\footnotetext{
${ }^{3}$ This was an internet-based survey carried out at the University of Melbourne, Australia, led by the chief investigator John de New. Ethical approval for the project was obtained from the University of Melbourne (Australia) Human Research Ethics Committee (Approval ID: 2056701.1).
} 
USA, UK, Spain, Italy, and Germany, although in this study we restrict our analysis to respondents who stated in the survey that they lived in Australia. 99.6\% of the impressions and $99.9 \%$ of link clicks of these campaigns were generated via the Facebook newsfeed. The advertisements had an average cost of $\$ 0.31$ per link click. Approximately $81 \%$ of the impressions ${ }^{4}$ ( $82 \%$ of link clicks) were generated via the mobile app, $9 \%$ via the mobile web (12\%), and $9 \%$ via the desktop (7\%). As respondents were not paid to participate in the survey, the survey was kept short to maximise response rates. It took participants on average 8 min (median: $7 \mathrm{~min}$ ) to complete the survey.

Of those who said that they were Australian residents, in the labour force, and between 18 and 64 years old (2619 observations), we drop 9\% who filled out the survey more than once ${ }^{5}$ in order to create a cross-sectional dataset. Of the remaining 2375 unique observations, $87 \%$ had non-missing information in the variables needed for the analysis, leading to a final analysis sample of 2078 Australian residents as of July 7, 2020. The advertisements were not targeted at specific socio-demographic characteristics such as by gender. This led to an over-representation of women in the sample $(86 \%$ in the sample vs $48 \%$ in the corresponding Australian labour force population), as has been documented occurring previously in social media-based advertising campaigns (Ali et al. 2020). People living in Victoria were also oversampled (46\% vs 27\%) as well as the older age groups (age 55-64: $24 \%$ vs 15\%). To make the sample representative of the general Australian population, we apply population weights based on the age, gender, occupation, and state composition of the Australian working population, from the 2016 Census, throughout the analysis. Appendix Table 2 compares the descriptive statistics of the weighted with the unweighted data as well as the descriptives for the total population. Weighting achieves an excellent match to the total population compositions with respect to age, gender, occupation, state, household size, and employment status. The unemployment rate is slightly higher in the weighted sample than the Australian one from the 2016 Census (8\% compared to $7 \%$ ), which is to be expected and in line with the increasing unemployment rates in June 2020 due to the pandemic.

While online surveys are now common in social sciences, some limitations should be considered. Even though we use Census-based population weights, as with any mode of survey delivery such as quota-based telephone surveys, there is still the possibility that people self-select into the survey based on other unobserved characteristics, including concern with the research topic, in our case the pandemic. An additional factor with online surveys is that they miss people who do not have a mobile device or computer with access to the internet, although this issue has become less in recent years with the rapid availability of online technologies. As our advertisement analytics show, the majority of people accessed the survey via the mobile app ( $82 \%$ of link clicks generated through the campaigns). Furthermore, it has been recently shown that "re-weighted online samples can produce response patterns that are indistinguishable, statistically and quantitatively, from those of mixed-mode survey", and thus be

\footnotetext{
${ }^{4}$ The number of times the advertisement was on a screen.

5 This was identified through respondents' email addresses, as individuals were encouraged to leave their email addresses for linking them over time. However, according to the conditions of the ethics approval, no attempt to re-contact the respondents by their email addresses was permitted. As only $9 \%$ of individuals could be tracked over time, we decided not to use the potential longitudinal aspect of the study in this paper.
} 
representative of the entire population (Grewenig et al. 2018). Grewenig et al. (2018) showed that this is because differences between offliners and onliners in the mixedmode survey can be attributed to face-to-face vs online survey mode effects rather than differences in unobserved characteristics.

An advantage of online recruitment through advertisements compared to crowdsourcing service sites such as Mechanical Turk is that advertisements tend to attract people from more diverse backgrounds, as respondents are reached who were not looking to participate in a study (Antoun et al. 2016). Online surveys are also less likely to suffer from social desirability bias than face-to-face sampling methods (Grewenig et al. 2018). Our results have to be interpreted in light of these advantages and disadvantages with each recruitment method and survey mode.

\subsection{Financial wellbeing}

Financial wellbeing has been defined in many ways in previous research. We follow Comerton-Forde et al. (2018:6), who reviewed many different conceptualisations and developed a definition that was appropriate for the Australian context. They define financial wellbeing as "the extent to which people both perceive and have (i) financial outcomes in which they meet their financial obligations, (ii) financial freedom to make choices that allow them to enjoy life, (iii) control of their finances, and (iv) financial security - now, in the future, and under possible adverse circumstances." Their definition incorporates elements that have been considered in other definitions, including those proposed by the U.S. Consumer Financial Protection Bureau (2017), Muir et al. (2017), and Netemeyer et al. (2018). Working from this definition and based on a set of 33 initial questions, Comerton-Forde et al. (2018) undertook a rigorous psychometric analysis, including factor analyses and Item Response Theory (IRT) modeling, to develop a 10-item scale of self-reported financial wellbeing. Botha et al. (2020b) derived an abbreviated 5-item version of the scale, found that it has high reliability (Cronbach's alpha was 0.86 ), and showed that it performs very similarly to the original 10-item scale. The IRT results also demonstrated that each of the responses to each of the 5 items provides significant and unique information to the underlying financial wellbeing construct and that each of the items discriminates nearly equally well. To keep the total survey length to $10 \mathrm{~min}$, the COVID-19 and YOUR Wellbeing Survey used the 5-item scale.

In addition to being rigorously validated, our measure of financial wellbeing is distinct from other related concepts and offers several advantages. Financial wellbeing is positively correlated to income, yet they are distinct constructs. Several studies provide evidence on this, including Bonke and Browning (2009); Brown and Gray (2016), Schmeiser and Seligman (2013), and Shim et al. (2009). When analysing financial wellbeing, Haisken-DeNew et al. (2018) show that people experience a range of financial wellbeing outcomes at all levels of income, with some high-income people experiencing modest financial wellbeing and some low-income people experiencing good financial wellbeing. As an individual outcome measure, financial wellbeing is preferable to income in that it is multi-faceted, capturing several dimensions of individual financial enjoyment such as uncertainty and future-oriented consumption that a simple income measure cannot. It also uses several items across a range of outcomes, averaging out measurement error. Finally, it can be constructed from only a 
few unintrusive questions that most survey respondents will gladly answer, whereas income item nonresponse in surveys is pervasive and troublesome for statistical analysis (Riphahn and Serfling 2005).

Our multi-item, concrete outcome-based, measure of financial wellbeing is also superior to single-item financial satisfaction measures, where it is unclear what the people answering this one subjective question think of, which makes comparisons across groups very difficult. Bond and Lang (2019) demonstrate the difficulties of identifying differences between group averages based on these single-item ordered questions. Moreover, Comerton-Forde et al. (2018), among others, find that financial satisfaction questions have poor psychometric properties (e.g. show patterns of extreme reporting). Financial wellbeing, and in particular the financial wellbeing measure we use in this paper, addressed specifically many of these shortcomings.

Finally, in contrast to most existing financial wellbeing measures, the financial wellbeing instrument used in this paper has been rigorously tested and validated. See Comerton-Forde et al. (2020) for a thorough review of the existing literature. Moreover, our chosen financial wellbeing measure is explicitly designed to maintain its measurement properties when the 5 items are combined in a summative scale, making this scale more transparent and simpler to implement than other financial wellbeing scales constructed with data-specific item weights such as factor loadings.

Figure 1 lists each of the possible responses for each of the five items in our financial wellbeing scale and shows the proportion of people who selected each response. The items cover current and future dimensions of financial wellbeing. Items 1,3 , and 4 relate to respondents' immediate day-to-day financial outcomes; item 2 relates to maintaining future financial wellbeing during unexpected events; and item 5 relates to sustaining financial wellbeing over time and reaching long-term financial goals.

Botha et al. (2020b) reported results from factor analyses that showed that all five items load on a single factor. The financial wellbeing scale is obtained by simply summing the five items and multiplying the sum by five to obtain a financial wellbeing score that ranges from 0 (low financial wellbeing) to 100 (high financial wellbeing); this scale has a reliability coefficient of 0.91 in this dataset. ${ }^{6}$ Across all items, a significant portion of people report low financial wellbeing. For example, $16 \%$ report that they cannot enjoy life at all or very little because of the way they are managing their money; 29\% could not handle a major unexpected expense at all or very little; $18 \%$ do not feel on top of their finances; $21 \%$ are not comfortable with their current level of spending; and 34\% report not to have enough money to provide for their financial needs in the future.

\subsection{Covariates}

The core explanatory variables for our analyses relate to events specifically because of COVID-19. We ask: "Regarding the worldwide Corona Virus COVID-19 pandemic, there have been many far-reaching economic and social implications, even if you or

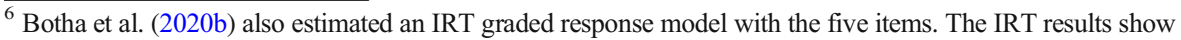
that each item has similar discrimination and that a summative scale is appropriate. The Spearman correlation between the summative scale and the latent predicted score from the IRT model is 0.996 suggesting that the simple summation financial wellbeing index is highly correlated with the latent financial wellbeing score.
} 


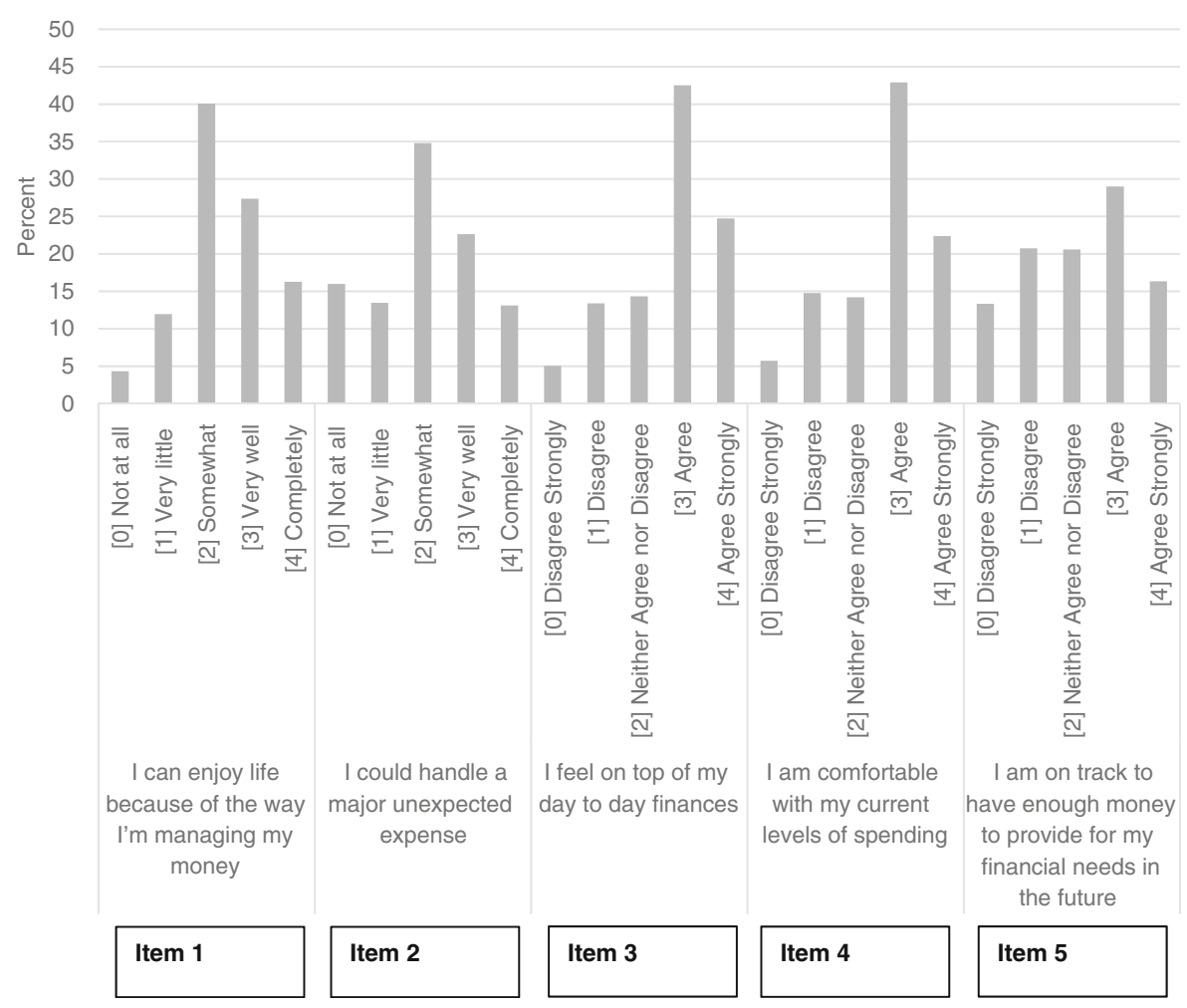

Fig. 1 Financial wellbeing components of financial wellbeing scale. Note: The graph shows the underlying components of the financial wellbeing scale and the proportion of people who selected each potential answer per component. $N=2078$

your family does not have the virus. Because of COVID-19, since Dec 1, $2019^{7}$ have you experienced any of the following (may choose multiple):

- $\quad$ Reduced Work Hours

- Reduced Wage/Salary

- Loss of employment or business closure

- Filed for Unemployment Benefits/Insurance/Assistance"

The terminology of "benefits" has been kept purposefully generic to be applicable worldwide; however, in Australia, these benefits relate specifically to "JobSeeker" government programs (a minimal base-level unemployment assistance) and are a fixed base amount paid fortnightly. ${ }^{8}$ Anyone fulfilling the requirement of officially looking

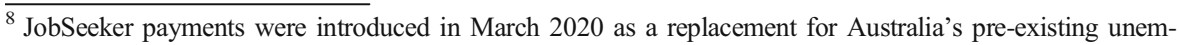
ployment benefit called the Newstart allowance, which had been in place since the early 1990s. As with Newstart, JobSeeker could include recipients with disabilities and parenting responsibilities that prevent them from pursuing full-time work, as well as some recipients who are not required to search for work. The base rate is $\$ 565.70$ per fortnight, and is bolstered by a $\$ 250$ Coronavirus Supplement during the pandemic. See https:// www.servicesaustralia.gov.au/individuals/services/centrelink/jobseeker-payment and https://reasury.gov.au/ coronavirus for further details.
} 
for work would normally receive these benefits. Those who had left the labour market would not have been eligible for benefits, until actively seeking re-employment. We combine the shocks of entry into unemployment or applying for benefits to reflect the Australian "JobSeeker" population. We combine the shocks of salary reduction and hours worked reduction to reflect the nature of the Australian "JobKeeper" population (short time work benefits, or wage subsidies paid through the employer, for those officially still classified as "employed", but facing reduced industry demand and potentially reduction in work hours). ${ }^{910}$

We consider the association with financial wellbeing of each of the two labour market shocks, and also of whether a person has experienced either of these shocks. ${ }^{11}$ Additional demographic controls include the respondent's age group, gender, occupation field, household size and Australian state, a linear time trend, and a time trend-state interaction. Given the 10-min response limit of the online survey, elicitation of additional demographic information was not possible.

Appendix Table 2 reports the descriptive statistics on the main variables used in this paper, including a comparison of the unweighted, weighted and populationlevel descriptives. The weighting achieves a good representativeness across the key variables. Therefore, all descriptive tables and figures as well as estimations use weights from hereon, unless otherwise specified. Mean (weighted) financial wellbeing is 59.3 on the $0-100$ scale. The percentile ratios indicate the presence of substantial inequality in the financial wellbeing distribution: $90 / 10=3.80 ; 75 / 25=$ $2.00 ; 90 / 50=1.46 ; 10 / 50=0.39$ and the Gini index is $0.234 .{ }^{12}$ About $29 \%$ of respondents experienced a reduction in working hours and salaries, whereas about $26 \%$ experienced job loss and/or had to apply for unemployment benefits. Almost $36 \%$ of Australian residents experienced at least one labour market shock. Appendix Table 3 shows that the labour market shocks of the pandemic seem to be felt across all demographic groups, but especially by women, the young, those in larger households (likely families with several children), and those working as sales workers and labourers.

Figure 2 depicts the observed or "factual" distribution of financial wellbeing as well as the distribution for the "treated" (those who experienced COVID-19 labour

\footnotetext{
${ }^{9}$ JobKeeper payments were also introduced in March 2020 as a new direct subsidy to businesses through the course of the coronavirus outbreak to keep staff in employment. Businesses with a turnover of less than $\$ 1$ billion had to show that they had a fall in turnover of at least $30 \%$ (at least $50 \%$ if turnover is $\$ 1$ billion or more). Eligible employers could claim $\$ 1500$ per fortnight before tax for the wages they had paid per employee. The full amount of the JobKeeper payment they received had to be passed on to the nominated employees. See https://treasury.gov.au/coronavirus/jobkeeper for more details.

${ }^{10}$ Of the $39.9 \%$ who experience either a salary reduction or a reduction in work hours, the majority of this subgroup (71.5\%) experienced both shocks simultaneously due to COVID-19. Rather than investigating the associations of the two shocks separately, which affect mostly the same population, we focus on the subgroup of people who experienced both of those shocks, which is reflective of a clear economic disadvantage and comprises people who would qualify for the JobKeeper program.

${ }^{11}$ The correlation coefficient between the two shocks is 0.58 .

${ }^{12}$ We use Jenkins (1999) Stata ADO file "povdec0.ado", which allows calculation of inequality measures for scales that include the value zero $(0)$.
} 
market shocks). ${ }^{13}$ The largest mass of the observed distribution is between 55 and 75 on the financial wellbeing scale of $0-100 .{ }^{14}$ This picture changes dramatically for the distribution for the treated only (having experienced a COVID-19-related labour market shock), with its mass situated much further to the left. ${ }^{15}$

\section{Empirical strategy}

\subsection{Average associations}

First, we estimate standard linear models for financial wellbeing, using the crosssectional data, in which we regress financial wellbeing, $F W B_{i t}$, on each of the COVID-19-related labour market shocks, $S_{h o c k}$, in separate regressions:

$$
\begin{aligned}
& F W B_{i t}=\alpha+\beta \text { Shock }_{i t}+\gamma_{1} \text { Demog }_{i t}+\gamma_{2} \text { LabMkt }_{i t} \\
& \quad+\gamma_{3} S_{i t}+\gamma_{4} \text { TimeTrend }_{t}+\gamma_{5} \text { TimeTrend }_{t} \times S_{i t}+\varepsilon_{i t}
\end{aligned}
$$

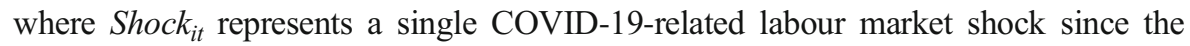
beginning of the pandemic, namely either (a) having experienced a reduction in earnings and hours worked, (b) entry into unemployment or having filed for unemployment benefits, or (c) having experienced either ${ }^{16}$ shock (a) or (b); Demog it represents age, gender, and household size indicators; LabMkt $t_{i t}$ contains occupation dummies reflecting being in employment in a specific occupation group at time $t$ (reference: unemployed); $S_{i t}$ is a set of dummies for the Australian states or territories; TimeTrend $_{t}$ is a linear time trend by week of the year and TimeTrend ${ }_{t} \times S_{i t}$ reflects the interactions between the time trend with each state, and $\varepsilon_{i t}$ is an error term. Our estimate of interest, $\widehat{\beta}$, captures the financial wellbeing gap between otherwise similar people, who did and did not suffer from a COVID-19-related labour market shock. We are interested in the association of financial wellbeing with these COVID-19-related labour market shock variables, net of their relationship with contemporaneous employment status.

\footnotetext{
${ }^{13}$ We refer to the "factual distribution" to mean the observed (and weighted) distribution as opposed to the counterfactual distribution which is not observed.

${ }^{14}$ As the observed distribution seems to have slightly higher proportions at the upper end compared to a previous distribution of financial wellbeing in Australia (Haisken-DeNew et al. 2018; Botha et al. 2020b), we have a slight over-representation of people in our data who report high financial wellbeing across the various items that make up the financial wellbeing measure. However, the results of our main analyses in Section 4 are robust to alternative estimations where we exclude the extreme and moderate financial wellbeing responses of either 0,2 or 4 across all items (leading to a value of 0,50 , or 100 in the composite measure). The association at the mean for AnyShock drops only slightly from -17.1 to -16.3 (both significant at the $0.1 \%$ level).

${ }^{15}$ Compared to recent analyses of financial wellbeing in Australia by Haisken-DeNew et al. (2018), we find that the fundamental relationship between financial wellbeing and key economic indicators remains unchanged in 2020. For example, we find similar differences in financial wellbeing across gender, state, and employment status.

${ }^{16}$ We have also constructed a dummy variable BothShocks in which both shocks (a) and (b) are experienced. As the results are very close to those of AnyShock and do not change any conclusions, they have not been included.
} 


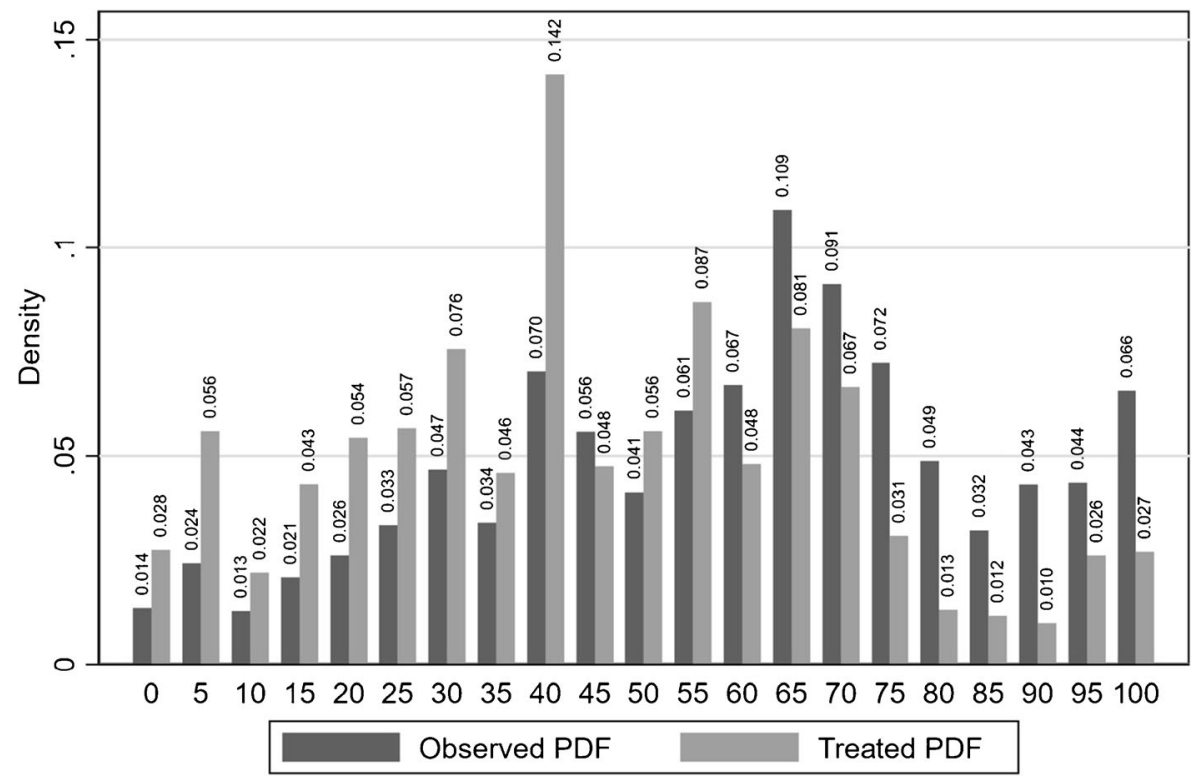

Fig. 2 Distribution of financial wellbeing (FWB): observed and treated (any COVID-19 shock). Note: The graph compares the observed probability density function (PDF) of financial wellbeing (dark grey bars) to that of the "treated" subpopulation of those who have experienced any COVID-19 shocks (light grey bars), as factually observed. All statistics are Census population weighted for representativity. $N=2078$

While the extent and depth of COVID-19 labour market shocks were hardly correctly predicted by anyone in Australia in early 2020, simply by the nature of people's observable characteristics such as occupation, age, and gender, some people are more susceptible to suffer the labour market consequences. Financial wellbeing could also differ across these characteristics, which could create a bias in our estimates. To the extent that we control for these characteristics, $\widehat{\beta}$ reflects financial wellbeing gaps, net of these confounding influences. Still, other unobservable characteristics might make certain groups more at risk of experiencing a COVID-19-related labour market shock while at the same time impacting their financial wellbeing. Because of this, we cannot interpret $\widehat{\beta}$ as a causal effect in Eq. (1), yet we still think of it as an informative statistic. Strong negative associations between COVID-19-related labour market shocks and financial wellbeing indicate that either financial wellbeing is so low because of the shock (a causal pathway), or it indicates that those most exposed to COVID-19 labour market shocks are also exposed to other factors that decrease their financial wellbeing. Either way, it points to substantial inequalities in the experience of the pandemic, in terms of the experienced impact or exposure to labour market shocks by those who are already "doing it tough". Our estimates will likely capture both mechanisms and in the following section we investigate the extent to which our data allow us to disentangle the causal impact from the effect of exposure to other factors we do not observe. 


\subsection{Estimate bounds}

Given the parsimonious nature of the short 10-minute survey, we can only control for a limited number of socio-demographic indicators such as occupation, age, and gender. This leaves open the possibility of omitted variable bias. For example, it is possible that less-skilled individuals disproportionately suffer the labour market burden of COVID19 , while also already experiencing lower financial wellbeing.

Thus, we also test the sensitivity of our results of the associations of COVID-19 labour market shocks with financial wellbeing by calculating bounds for the estimates of the $\beta$ coefficient in Eq. (1) based on assumptions about how the selection on unobservables could be proportional to the selection on observables in our data. We implement the Altonji et al. (2005) and Oster (2019) methods for these calculations. ${ }^{17}$ For a coefficient of negative value, the lower bound $\beta_{0}$ is calculated on the basis that the proportional degree of selection on unobservables to selection on observables is 0 ( $\delta=$ 0 ) and is therefore equivalent to our linear estimate for $\beta$, while the upper bound $\beta_{1}$ is calculated on the basis that the amount of selection on unobservables is equal to selection on observables $(\delta=1)$. This is a reasonable upper bound under three assumptions (see Altonji et al. 2005, p. 170, for a detailed explanation). The first assumption is that the number of observable and unobservable determinants of financial wellbeing is large and that none of them dominates the distribution of either financial wellbeing or of COVID-19-related labour market shocks. This assumption is not unlikely to hold in our case since (i) both financial wellbeing and COVID-19 labour market conditions are complex and multi-faceted, (ii) any one survey can only measure a few of their determinants, and (iii) our survey did measure several key socio-demographic characteristics that are generally important for both outcomes. The second assumption is that the observables chosen act as a "random sample" of all determinants of financial wellbeing. This assumption is more contentious in our case since our survey was tailored to measure shocks likely to affect financial wellbeing (among other outcomes). Yet in our empirical design, we did not actively choose measures that were good predictors of financial wellbeing (such as those included in the conceptual framework or empirical analyses of Comerton-Forde et al. 2020). Our chosen covariates are standard in most micro-econometric analyses of labour market outcomes and, to that extent, they can also be considered a reasonably random sample of the determinants of financial wellbeing. Moreover, to the extent that we might have included stronger-thanrandom covariates in our analyses, our $\left[\beta_{0}, \beta_{1}\right]$ bounds would perform even better (see Oster 2019:197). The third assumption imposes some conditions on the informativeness of observables that is better explained in Altonji et al. (2005), yet they argue these conditions are no stronger than those needed for standard OLS estimates. Overall, we view these bounds as very informative in the same way that various other studies, in their own contexts, have done before (e.g., Mian and Sufi 2014; Alesina et al. 2016; Hanushek et al. 2017). We therefore take the view that unobservables should not be more important than our chosen observables in our analyses, lending validity to our

\footnotetext{
${ }^{17}$ Emily Oster provides a Stata ADO file called "psacalc.ado" which provides the upper bound estimator for our results in addition to $\delta$, the degree of selection on unobservables proportional to the selection on observables required to explain away our estimated effect. The estimated bounds and $\delta$ are equivalent ways of estimating the sensitivity of our results to proportional selection. See Oster $(2013,2019)$ for further details.
} 
bounding exercises. We also report the amount of selection on unobservables, relative to selection on observables, for the estimated effect to become insignificant.

\subsection{Quantile regressions}

While the above regressions provide estimates of average associations of the Shock variables with $F W B_{i t}$, one cannot immediately rule out substantial distributional associations. If one is already low in the $F W B_{i t}$ distribution, those suffering any number of COVID-19-related shocks will likely have a larger decrease in financial wellbeing than average or even than someone with higher initial levels of financial wellbeing. For targeted policies to help the most unfortunate, the relationship in the left tail of the financial wellbeing distribution should receive special attention.

To address this, we also estimate quantile regressions for $F W B_{i t}$ to determine whether the association between COVID-19's labour market shocks and financial wellbeing is different across the $F W B_{i t}$ distribution. We produce unconditional quantile estimates introduced by Firpo et al. (2009), which have the interpretation of the size of the association at a given point in the $F W B_{i t}$ distribution. ${ }^{18}$ Unconditional quantile regressions produce economically intuitive estimates, recovering marginal effects of covariates at the, say, 10 th percentile of the financial wellbeing distribution. In contrast, conditional quantile regression estimates will recover marginal effects at the 10th percentile of the financial wellbeing distribution conditional on covariates, which is much more difficult to interpret and might be an altogether different person. For example, it could happen that conditional on education, income and employment status, the person at the 10th percentile of the conditional financial wellbeing distribution could actually be at the 30th percentile in the unconditional financial wellbeing distribution. A second advantage of unconditional quantile regressions is that they are more easily estimable via a series of OLS estimates rather than by maximising a complex likelihood function.

\subsection{Counterfactual distributions}

Given that we identify differential associations of the Shock ${ }_{i t}$ variables over the $F W B_{i t}$ distribution, we are interested to know what the $F W B_{i t}$ distribution would have counterfactually looked like, had these individuals not experienced $S h o c k_{i t}$. Is the experience of $S_{h o c k}$ associated with a change in the $F W B_{i t}$ distribution? Is the $F W B_{i t}$ distribution more unequal due to its association with COVID-19 unemployment shocks Shock $_{i t}$ ?

To address these questions, our final analyses implement distribution regressions (see Chernozhukov et al. 2013, 2020a; Chernozhukov et al. 2020b; and Van Kerm 2015 for further details on distribution regression). ${ }^{19}$ Compared to the unconditional quantile regressions used above, distributional regressions are better suited for

\footnotetext{
${ }^{18}$ We use Fernando Rios-Avila's code contained in the Stata ADO "rifhdreg.ado", which calculates recentered influence function regressions. See Rios-Avila (2020) for further details.

${ }^{19}$ The results from the distribution regressions are entirely consistent with a DiNardo et al. (1996) analysis treating the financial wellbeing variable as a continuous variable rather than a variable that contains a collection of discrete values as in the distribution regression analysis. An earlier working paper version of this paper shows a comparable analysis (Botha et al. 2020a). Results are available upon request.
} 
constructing counterfactual distributions using off-the-shelf statistical packages that have been carefully curated. We start with the original OLS regression in (2), with the same regressors:

$$
\begin{aligned}
F W B_{i t} & =\alpha+\beta \text { Shock }_{i t}+\gamma_{1} \text { Demog }_{i t}+\gamma_{2} \text { LabMkt }_{i t}+\gamma_{3} S_{i t} \\
& +\gamma_{4} \text { TimeTrend }_{t}+\gamma_{5} \text { TimeTrend }_{t} \times S_{i t}+\varepsilon_{i t}
\end{aligned}
$$

and replace the outcome variable $F W B_{i t}$ with a series of dummy variables $f w b R_{i t}$ such that:

$$
\begin{gathered}
\left.f w b 0_{i t}=1, \text { if } F W B_{i t}>0 \text { (and } 0 \text { otherwise }\right), \\
f w b 5_{i t}=1, \text { if } F W B_{i t}>5(\text { and } 0 \text { otherwise }), \ldots, \\
f w b \mathrm{R}_{i t}=1, \text { if } F W B_{\text {it }}>R(\text { and } 0 \text { otherwise }) \text { for } R=10,15, \ldots, 90 \\
\left.f w b 95_{i t}=1 \text {, if } F W B_{i t}>95 \text { (and } 0 \text { otherwise }\right) .
\end{gathered}
$$

Thus, for the 21 discrete values of $F W B_{i t}$, we estimate 20 separate linear probability models and obtain a separate estimate for the regressors for the dependent variable being greater than the threshold $R$ in question, as in:

$$
\begin{aligned}
\text { fwbR }_{i t}=\alpha^{R}+ & \beta^{R} \text { Shock }_{i t}+\gamma_{1}^{R} \text { Demog }_{i t}+\gamma_{2}^{R} \text { LabMkt }_{i t}+\gamma_{3}^{R} S_{i t} \\
& +\gamma_{4}^{R} \text { TimeTrend }_{t}+\gamma_{5}^{R} \text { TimeTrend }_{t} \times S_{i t}+\varepsilon_{i t}^{R}
\end{aligned}
$$

for each financial wellbeing threshold $R=0,5,10, \ldots, 95$.

An interesting property of (linear) distribution regression is that summing up the respective linear probability model coefficients over the entire $F W B_{i t}$ distribution gives exactly the overall OLS estimate in (2), but we see the influence of the explanatory variables at every point in the outcome variable distribution. ${ }^{20}$

Distribution regression gives us an idea of the magnitude of the association at a particular value in the distribution of the outcome variable, but weighted by the corresponding mass of observations. For example, there could be much smaller associations in the middle of the distribution of financial wellbeing, but if far more people are sitting at these points in the distribution, the overall influence of these associations may be the greatest. Distribution regressions allow us to quantify this relationship.

Distribution regressions also allow us to simulate a counterfactual distribution for the treated. Thus, for those individuals who experienced a COVID-19 Shock ${ }_{i t}$, we can calculate (1) an observed distribution of financial wellbeing, and (2) a counterfactual distribution of financial wellbeing, in which we remove the association with Shock $_{i t}$ throughout the financial wellbeing distribution. For the treated, observed, and counterfactual distributions, we calculate the Gini inequality coefficient, the values of financial

\footnotetext{
${ }^{20}$ It is slightly more complicated than that. There are 21 discrete values of financial wellbeing between 0 and 100 (in steps of 5), but 101 distinct values. Thus, the regression for $f w b 0$ and $f w b 1, \ldots, f w b 4$ are all identical. Similarly, this holds for $f w b 5$ and $f w b 6, \ldots, f w b 9$, and so on (in groups of 5). The summation of all the coefficients for $f w b 0,1,2,3,4, \ldots, 99$ is required to give the identical result as that of the standard OLS estimate.
} 
wellbeing at the median, and the 10th percentile and the 90th percentile as measures of inequality in financial wellbeing.

\section{Results}

\subsection{Average associations and across the distribution of financial wellbeing}

The main regression results of the estimates of interest are presented in Table $1 .{ }^{21} \mathrm{We}$ report the linear estimates in panels $1 \mathrm{~A}-1 \mathrm{C}$, column (1), that show the average (OLS) association of the COVID-19 labour market shocks with financial wellbeing. In addition, to examine the associations of COVID-19 labour market shocks over the distribution of financial wellbeing, the unconditional quantile regression estimates for financial wellbeing at the 10th, 25th, 50th, 75th, and 90th percentiles are reported in columns (2)-(6). In all estimations, we control for demographic characteristics, labour market status, and occupation as well as state fixed effects and state-specific week of the year linear time trends.

Considering the linear results, having experienced a labour market shock of any type is associated with significantly lower levels of financial wellbeing. Having had, for example, a reduction in salary and working hours is related to an 18.9-point decrease in financial wellbeing ( 0 to 100 ) relative to people who did not experience such a shock. This is equivalent to levels of financial wellbeing reduced by $32 \%$ compared to the mean of 59.3. Having been made redundant or having been forced to apply for unemployment benefits is associated with a similar 13.2-point drop in financial wellbeing (reduction of 22\%). Having experienced either shock is associated with a 17.1-point decrease in financial wellbeing (reduction of 29\%). It is worth noting that in these COVID-19 crisis times, having experienced reductions in salary and hours worked is statistically equivalent to the shock of unemployment due to COVID-19. All three scenarios are statistically identical in the magnitude of the associated shock, so we will focus here primarily on the results for "any shock".

Using the Altonji et al. (2005) and Oster (2019) calculations, and maintaining their assumption as described in Section 4.2, we place an upper bound of the estimated associations at the mean. For example, on average, having a direct COVID-19-related reduction in salary is associated with a drop in financial wellbeing of 18.9 points on the $0-100$ scale. Using the Altonji et al. (2005) and Oster (2019) calculations and assuming a $R_{\max }=1.3\left(R^{2}\right)$, where $R^{2}$ is from the OLS regressions with all controls, we place an upper bound of the effect at -17.0 points when assuming that selection on unobservables is equal to that of observables. Selection on the unobservables would have to be 3.79 times higher than that on the observables to render the reduction in salary and hours coefficient insignificant (Table 1, panel 1A). As this calculation

\footnotetext{
${ }^{21}$ Only the coefficients of the relevant labour market shock indicators are reported in Table 2. The full regression results with any COVID-19 shocks as the main explanatory variable are reported in Appendix Table 4. Appendix Table 4 shows that the employed have significantly higher financial wellbeing levels, especially managers and professionals. The Northern Territory had significantly higher financial wellbeing across the distribution compared to the reference Victoria; however, there is a downward sloping linear time trend. It should be noted that the Northern Territory is the smallest in terms of population among the Australian states and had correspondingly the fewest respondents.
} 
Table 1 COVID-19 labour market shocks and financial wellbeing

\begin{tabular}{|c|c|c|c|c|c|c|}
\hline & (1) & (2) & (3) & (4) & (5) & (6) \\
\hline Variable & Mean & Q10 & Q25 & Q50 & Q75 & Q90 \\
\hline \multicolumn{7}{|l|}{$1 \mathrm{~A}}$. \\
\hline Salary and hours & $\begin{array}{l}-18.852^{* * *} \\
(2.184)\end{array}$ & $\begin{array}{l}-20.187^{* * * *} \\
(4.761)\end{array}$ & $\begin{array}{l}-25.344^{* * *} \\
(3.833)\end{array}$ & $\begin{array}{l}-20.454^{* * *} \\
(2.691)\end{array}$ & $\begin{array}{l}-14.833^{* * *} \\
(2.470)\end{array}$ & $\begin{array}{l}-4.428 \\
(3.057)\end{array}$ \\
\hline [Bounds: $\left.\beta_{0}, \beta_{1}\right]$ & {$[-18.852,-17.00]$} & - & - & - & - & - \\
\hline $\begin{array}{l}\delta \text { req'd for } \beta=0 \\
\text { 1B. }\end{array}$ & 3.79 & - & - & - & - & - \\
\hline UE or benefits & $\begin{array}{l}-13.213^{* * *} \\
(2.630)\end{array}$ & $\begin{array}{l}-13.218^{\text {** }} \\
(4.756)\end{array}$ & $\begin{array}{l}-14.986^{\text {**** }} \\
(4.332)\end{array}$ & $\begin{array}{l}-14.088^{* * *} \\
(3.444)\end{array}$ & $\begin{array}{l}-14.009^{* * * *} \\
(2.824)\end{array}$ & $\begin{array}{l}-4.730 \\
(3.373)\end{array}$ \\
\hline [Bounds: $\beta_{0}, \beta_{1}$ ] & {$[-13.213,-8.61]$} & - & - & - & - & - \\
\hline $\begin{array}{l}\delta \text { req'd for } \beta=0 \\
1 \text { C. }\end{array}$ & 2.04 & - & - & - & - & - \\
\hline Any shocks & $\begin{array}{l}-17.110^{* * *} \\
(2.231)\end{array}$ & $\begin{array}{l}-19.477^{* * *} \\
(4.318)\end{array}$ & $\begin{array}{l}-20.509^{* * *} \\
(3.620)\end{array}$ & $\begin{array}{l}-16.865^{* * *} \\
(2.922)\end{array}$ & $\begin{array}{l}-16.337^{* * *} \\
(2.620)\end{array}$ & $\begin{array}{l}-5.957 \\
(3.294)\end{array}$ \\
\hline [Bounds: $\left.\beta_{0}, \beta_{1}\right]$ & {$[-17.110,-13.40]$} & - & - & - & - & - \\
\hline$\delta$ req'd for $\beta=0$ & I(90-10) & I(50-10) & I(90-50) & I(75-25) & I(50-25) & I(75-50) \\
\hline \multicolumn{7}{|l|}{$2 \mathrm{~A}}$. \\
\hline Salary and hours & $\begin{array}{l}15.759^{* *} \\
(5.319)\end{array}$ & $\begin{array}{l}-0.266 \\
(5.038)\end{array}$ & $\begin{array}{l}16.025^{* * * *} \\
(3.166)\end{array}$ & $\begin{array}{l}10.510^{* *} \\
(3.958)\end{array}$ & $\begin{array}{l}4.890 \\
(3.959)\end{array}$ & $\begin{array}{l}5.620^{*} \\
(2.718)\end{array}$ \\
\hline \multicolumn{7}{|l|}{$2 \mathrm{~B}$. } \\
\hline UE or benefits & $\begin{array}{l}8.489 \\
(5.389)\end{array}$ & $\begin{array}{l}-0.870 \\
(5.110)\end{array}$ & $\begin{array}{l}9.358^{*} \\
(3.937)\end{array}$ & $\begin{array}{l}0.977 \\
(4.445)\end{array}$ & $\begin{array}{l}0.898 \\
(4.219)\end{array}$ & $\begin{array}{l}0.079 \\
(3.549)\end{array}$ \\
\hline \multicolumn{7}{|l|}{$2 \mathrm{C}$. } \\
\hline Any shocks & $\begin{array}{l}13.520^{* * *} \\
(5.084)\end{array}$ & $\begin{array}{l}2.612 \\
(4.647)\end{array}$ & $\begin{array}{l}10.907^{\text {** }} \\
(3.567)\end{array}$ & $\begin{array}{l}4.172 \\
(3.837)\end{array}$ & $\begin{array}{l}3.644 \\
(3.649)\end{array}$ & $\begin{array}{l}0.528 \\
(3.038)\end{array}$ \\
\hline
\end{tabular}

Note: ${ }^{*} p<0.05,{ }^{* *} p<0.01,{ }^{* * * *} p<0.001 . N=2078$. All specifications shown include controls for demographics, labour market status, occupation FEs, state FEs, week time trend, and week $\times$ state. Heteroskedasticity-robust standard errors in parentheses. Each panel $1 \mathrm{~A}-1 \mathrm{C}$ is from a separate regression with financial wellbeing as the dependent variable. $R^{2}$ ranges from 0.181 to 0.233 in the OLS regression for the effects at the mean. The reported bounds show the sensitivity of the COVID-19 labour market shock estimates to selection on unobservables based on selection on observables. The bounds analysis assumes $R_{\max }=1.3\left(R^{2}\right)$, where $R^{2}$ is from the OLS regressions with all controls. The lower bound $\beta_{0}$ is calculated on the basis that the proportional degree of selection on unobservables to selection on observables is $0(\delta=0)$ and is therefore equivalent to our estimate for $\beta$, while the upper bound $\beta_{1}$ is calculated on the basis that the amount of selection on unobservables is equal to selection on observables $(\delta=1)$. The estimated $\delta$ suggests that there must be $\delta$ times the amount of selection on unobservables, relative to selection on observables, for the estimated effect to become insignificant. Demographic controls: age, gender, household size. Panels 2A-2C show the inter-percentile ranges at two points in the financial wellbeing distribution, e.g. the difference in financial wellbeing at the 90th percentile compared to that at the 10th percentile in column (1) labelled I(9010). The larger this number, the more dispersion is observed. All dispersion measures here are presented with their respective standard errors to indicate significance of the inter-percentile difference. These results follow from the regressions from the results in panels $1 \mathrm{~A}-1 \mathrm{C} . R^{2}$ ranges from 0.079 to 0.091 
depends on the chosen $R_{\max }$ as well as the included control variables, it only gives us an indication about the potential role of unobservables, but it is reassuring that all upper bounds of the negative coefficients are well below zero and that proportional selection on the unobservables would have to be quite high, between 2.04 and 3.79 times higher than selection on the observables to render the estimated coefficients insignificant. At a minimum, we cannot rule out that the estimated coefficients include at least partly causal effects running from a shock to a reduction in financial wellbeing.

Although the average associations of financial wellbeing with COVID-19 labour market shocks are large, these linear estimates at the mean obscure important differences across the financial wellbeing distribution. Specifically, examining the entire financial wellbeing distribution, in the quantile regression results (Table 1, panels 1A1C, columns (2)-(6)), labour market shocks have a much larger association with financial wellbeing of individuals in the lower parts of the financial wellbeing distribution, especially the 10 th and 25 th percentiles. The relationship between labour market shocks and financial wellbeing for those in the 90th percentile is insignificant and much smaller, only at around a third of the magnitude as in the left tail (10th percentile) of the distribution. The negative associations of labour market shocks with financial wellbeing generally increase in magnitude as we move leftward in the financial wellbeing distribution.

In Table 1, panel 1A for example, the association with a salary reduction is strongest for the 25th percentile with a drop of 25.3 points, whereas the 75 th percentile experiences only a 14.8-point drop for the same shock. This is likely due to the larger degree of asset income in the total portfolio of income sources of those in the 75th percentile, as opposed to the 25 th percentile relying predominantly on earnings income of wages and salary. Furthermore, the type of salary reduction may vary systematically over the distribution: those particularly well off may experience a salary reduction that affects bonuses or premiums, whereas the lower $25 \%$ may be affected by more binding reductions in their base or regular salaries. Overall the estimated patterns are surprisingly similar for experiencing a reduction in salary and hours (panel 1A) compared to unemployment and having to apply for benefits (panel 1B), as well as having experienced any shocks (panel 1C). Appendix Fig. 5 shows the estimated coefficients of having experienced any shocks (panel 1C) of the unconditional quantile regression at various slices of the financial wellbeing distribution as well as the linear estimate graphically.

Placing these numbers in relative terms, the associations at the bottom quarter of the financial wellbeing distribution are around $20 \%$ larger in magnitude than those at the median or the 75th percentile of the distribution. Truly stark distributional differences appear when we compare associations at the bottom quarter and the top decile of the financial wellbeing distribution; the association of COVID-19-related labour market shocks is overall 3.3 times larger in magnitude at the bottom than at the very top. These distributional differences are more strongly driven by salary and hours reduction than by entry into unemployment and/or applying for benefits, consistent with the large increases in unemployment benefits and business support implemented by the Australian government through JobSeeker and JobKeeper programs. We tackle the question of how different things could have been for affected people in the next section.

To ascertain whether the inter-percentile differences of experiencing COVID-19 labour market shocks are statistically significant, we calculate quantile effects on inter- 
percentile ranges together with standard errors. These are displayed in panels $2 \mathrm{~A}-2 \mathrm{C}$ of Table 1, in which we compare the distributional ranges, the widest 10-50-90 and the slightly narrower $25-50-75 .{ }^{22}$ In general, all three of the main labour market shocks have very similar magnitudes between them. Thus, the 10-90 distance for salary and hours reduction is statistically identical to entry into unemployment or having filed for unemployment benefits. Thus, for any shocks in panel 2C, we note that the difference between the 90th percentile and the 10th percentile of the financial wellbeing distribution is 13.5 points (and statistically significant). In the lower half of the distribution, the distance between the 10th percentile and the median is 2.6 points, although not significant. We compare this to the upper half of the distribution (90-50), where this difference is 10.9 points.

We can compare the 90-10 results to the more conservative 75-25 results, but still find statistically and economically significant differences (albeit slightly narrower) across the financial wellbeing distribution for (a) having experienced a reduction in earnings and hours worked, the more negative of the two shocks. For reduction in earnings and hours worked in 90-10, there is a 15.8-point significant difference, whereas for 75-25, this difference is significant yet slightly lower at 10.5.

Overall, panels 2A-2C of Table 1 show that COVID-19 labour market shocks are primarily related to lower financial wellbeing among people in the low end of the financial wellbeing distribution, and that these shocks are generally related to higher inequality in financial wellbeing. In the next section, we turn to our counterfactual distribution analyses where we focus solely on the association of experiencing any COVID-19 labour market shock since our estimates are so similar across panels A-C of Table 1.

\subsection{Counterfactual distributional analysis}

We examine the distributional implications using distribution regression as in Chernozhukov et al. (2013). The top part of Fig. 3a displays all of the point estimates for the linear probability models of Eq. (3) for the variable of interest "Any COVID-19 Shock". The point estimates are given by the solid black line, surrounded by $95 \%$ confidence intervals in green dashed lines. As indicated in the top part, all coefficients are displayed with their respective confidence intervals over the entire distribution of financial wellbeing. Furthermore, the $F$-test of jointly testing whether all coefficients are zero is rejected with higher than $99.9 \%$ level of confidence $\left(\chi^{2}=110.2\right.$ with 20 degrees of freedom). That would be true of the single OLS point estimate (with $95 \%$ confidence interval) as well, seen in the lower part of Fig. 3a (bold black line). Additionally, we test jointly whether the coefficients are significantly identical to each other. We reject this also with higher than $99.9 \%$ level of confidence $\left(\chi^{2}=\right.$ 105.7 with 19 degrees of freedom). The top panel of Fig. 3a demonstrates that the largest negative distributional association of "Any COVID-19 Shock" with the financial wellbeing distribution is seen between the values of financial wellbeing of 40 and 75 .

In Fig. 3b, for those individuals who experienced a COVID-19 Shock $k_{i t}$, we can calculate (1) an observed distribution of financial wellbeing, and (2) a counterfactual distribution of financial wellbeing, in which we remove the association with Shock ${ }_{i t}$ at

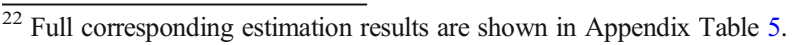




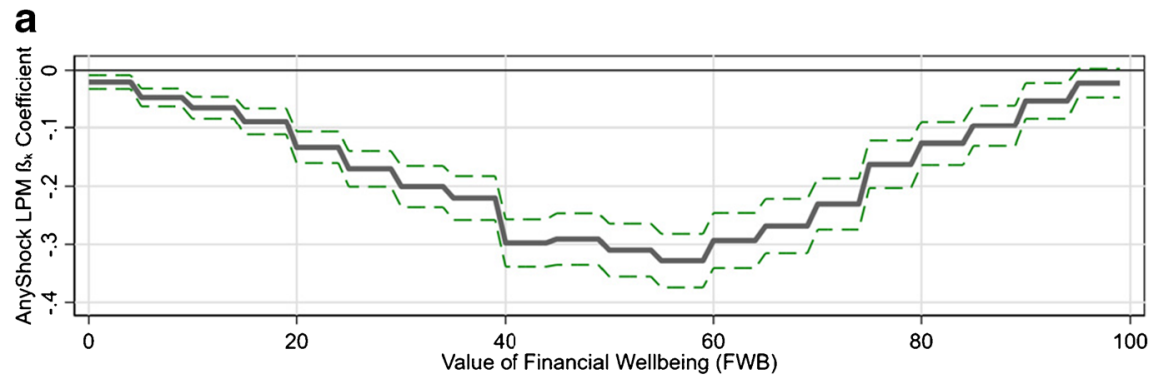

Joint Tests: $H 0$ : $\beta k=0 \forall k, k \in Y: X^{2}=110.2283(20) ; p=0.0000 ; H O: ß k=ß \mid \forall k \neq l, k, l \in Y: X^{2}=105.6885(19) ; p=0.0000$
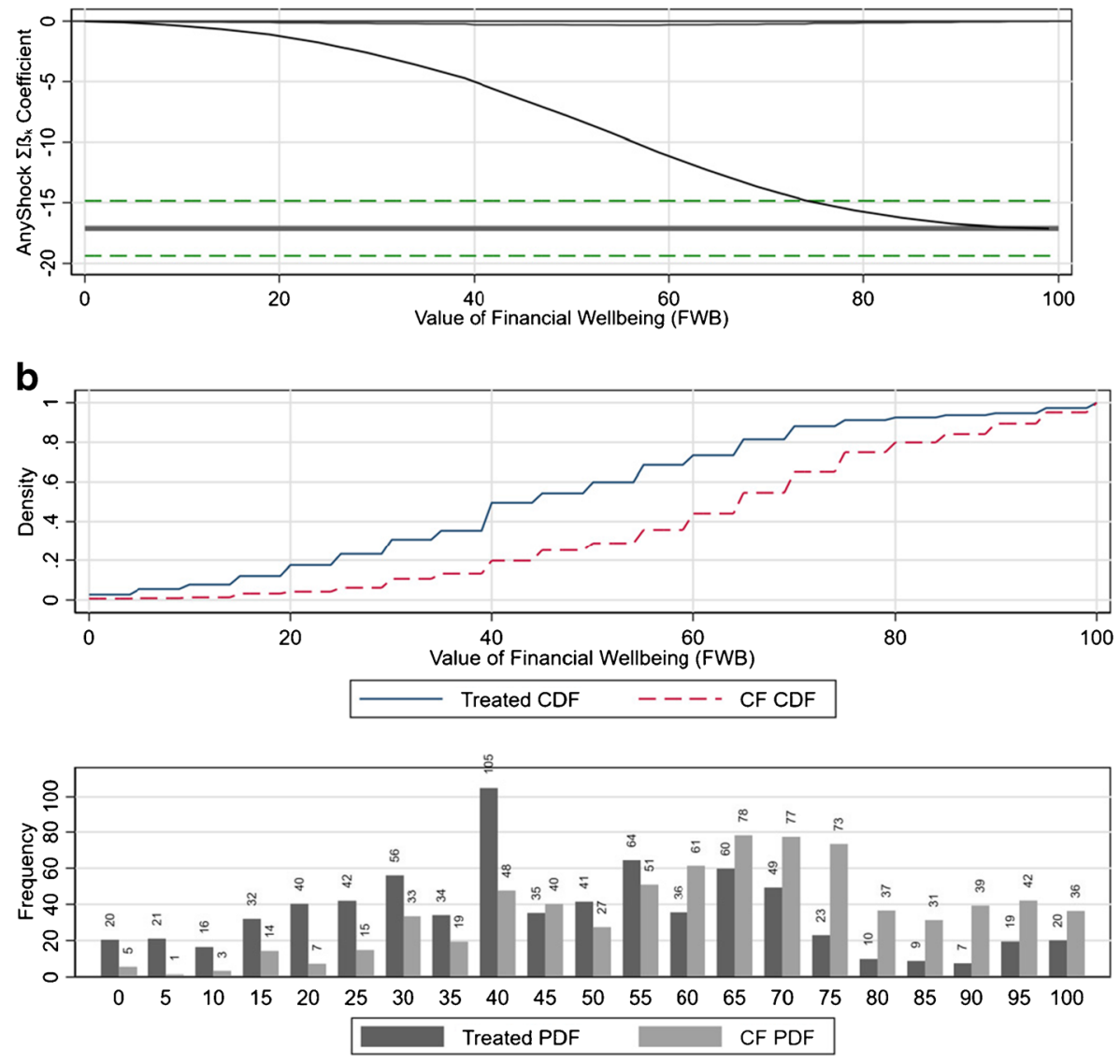
Treated PDF Gini $=0.275 ; Q(50)=45 ; Q(10)=15: Q(90)=75$
Counterfactual PDF Gini $=0.191 ; Q(50)=65 ; Q(10)=30 ; Q(90)=95$

each discrete value of the $F W B_{i t}$ distribution. Specifically, for each threshold point $R=$ $0,5,10, \ldots, 95$ in the financial wellbeing distribution, we construct the counterfactual value $\widehat{f w b}_{i t}^{R}-\widehat{\beta}^{R}$ Shock $_{i t}$; the combined set of these values is the counterfactual distribution. We provide the probability density functions (PDFs, bottom part) and the 
Fig. 3 Distribution regression: any COVID-19 shock. a Any shock $\beta$ over distribution of FWB. b Any shock CDF and PDF over FWB. Note: The top panel of a displays the individual distribution regressions (linear probability models or LPM) at every point in the financial wellbeing distribution. The point estimate is given by the dark black line and the respective $95 \%$ confidence interval by the surrounding dashed green lines. The summation of these individual associations over the entire distribution gives exactly the overall OLS coefficient, shown in the bottom panel of a (bold black line with dashed green line showing the $95 \%$ confidence interval). As the association with any COVID-19-related labour market shock (AnyShock) is negative, the negative association is summed up (the curved light black line) over the entire distribution of financial wellbeing and exactly equals the value of the estimated OLS coefficient. The "step function" appearance of the estimated coefficients in the top panel comes from the fact that there are at most 21 distinct values in the 0 through 100 scale $(0,5,10,15, \ldots, 100)$. The top panel of $\mathbf{b}$ shows for the group of people experiencing any COVID-19-related labour market shock (AnyShock) the observed cumulative density function (CDF) over the distribution of financial wellbeing (solid blue line). Using the coefficients of the distribution regression estimations, the association of AnyShock with financial wellbeing is removed, producing the counterfactual CDF shown in dashed red. The bottom panel displays the corresponding probability functions (PDF) as histograms. The dark bars display the values of financial wellbeing as observed for those experiencing AnyShock. The counterfactual histogram in lighter grey removes the association of AnyShock with financial wellbeing

cumulative density functions (CDFs, top part) of the observed and counterfactual distributions.

In the bottom panel of Fig. 3b, we see the treated PDF as observed (dark bars) and the counterfactual PDF (grey bars). As seen by the grey bars, removing the negative association with the COVID-19 shocks moves the mass of the distribution rightward. In the top panel of Fig. 3b, the observed CDF starts off much higher at lower values of financial wellbeing, as more of the mass is observed there. Between the financial wellbeing values of 40 and 70, the vertical distance between the treated CDF as observed and the counterfactual CDF is highest, indicating the largest influence in the distribution.

We see this numerically as well in the notes below the bottom panel of Fig. 3b, in which distributional statistics are reported. The median value of 45 in the observed distribution of the treated moves counterfactually to the right to 65 , having removed the negative association with COVID-19 shocks. The standard measure of inequality, the $90 / 10$ ratio, goes from $5(=75 / 15)$ to $3.2(=95 / 30)$. Similarly, the Gini inequality coefficient drops from 0.275 to 0.191 . If the outcome variable was income, these differences in inequality would be considered to be substantial in the international literature. While any COVID-19 labour market shocks have an overall average negative association of -17.1 points with financial wellbeing, there are substantial and significant distributional associations differing by position in the financial wellbeing distribution.

Effectively, our counterfactual distribution exercise shows that, had there been a way for people who indeed suffered any COVID-19 labour market shocks to have avoided them, we could have expected higher levels of financial wellbeing across the entire distribution. These higher levels of financial wellbeing would have been more marked around the middle of the distribution, which results from the large but relatively similar negative associations of COVID-19 labour market shocks across all but the top of the 
financial wellbeing distribution, combined with the fact that the bulk of the treated respondents are sitting around the middle of the distribution. Nevertheless, from Fig. 3, it is clear that the counterfactual distribution stochastically dominates the factual distribution for those who suffered from COVID-19-related labour market shocks: at every point in the financial wellbeing distribution someone would have had better chances of a higher financial wellbeing in the counterfactual than in the treated distribution. This does not happen mechanically in distributional regressions; it is a feature of the substantial labour market shocks experienced across the entire distribution of financial wellbeing.

\section{Conclusions}

In this study, we conducted an online survey COVID-19 and YOUR Wellbeing which surveyed internet respondents over 3 months of the beginning of the COVID-19 crisis in Australia (April-July 2020), and which was Census-weight-stratified to make it representative of the Australian population. We examine the financial wellbeing levels associated with having experienced (a) a reduction in earnings and hours worked or (b) entry into unemployment or having filed for unemployment benefits. Examining these relationships is important to identify vulnerable populations in the pandemic, necessary for targeting policy interventions, as well as understanding whether current government policies are sufficient to protect those vulnerable to labour market shocks and their potential financial wellbeing implications. Using a validated measure of perceived financial wellbeing, this is the first paper to quantify empirically the association of COVID-19-related labour market shocks with financial wellbeing.

An important contribution of our study is that we are able to elicit financial wellbeing via a multi-faceted measure that captures key elements such as uncertainty and future security which depend on people's financial reserves and behaviour, ability to shift expenses, government assistance, and available social resources. In comparison to focusing merely on income, our study on perceived financial wellbeing gives us a holistic view of the true pressures felt by all individuals across the income and wealth distribution during the pandemic.

We find that almost $36 \%$ of Australian residents report having experienced at least one labour market shock due to COVID-19. Similarly, a significant proportion of Australian residents report having troubles with their financial wellbeing. For example, $34 \%$ report not having enough money to provide for their financial needs in the future, $29 \%$ could not handle a major unexpected expense at all or very little, $21 \%$ are not comfortable with their current level of spending, $18 \%$ do not feel on top of their finances, and $16 \%$ report that they cannot enjoy life at all or very little because of the way they are managing their money.

Having experienced any of the examined COVID-19-related labour market shocks is significantly associated with a $29 \%$ reduction in financial wellbeing (or 17.1 points on the $0-100$ financial wellbeing scale). We identify large inequalities across the financial wellbeing distribution. Unconditional quantile analyses reveal that the relationship is 
strongest at the bottom of the distribution: for the 25th percentile, an experience of any of the shocks is associated with a drop of 21 points, whereas the 75th percentile experiences only a 16-point drop. Distribution regressions suggest large potential gains in financial wellbeing equality if one were to remove counterfactually the negative associations of COVID-19 labour market shocks across the financial wellbeing distribution. Specifically, we find that the standard measure of inequality, the 90/10 ratio, goes from 5 in the observed distribution of the treated to 3.2 having counterfactually removed the negative association with COVID-19 shocks; similarly, the Gini inequality coefficient drops from 0.275 to 0.191 , indicating reduced inequality. These conclusions are consistent with a corresponding DiNardo et al. (1996) decomposition in Botha et al. (2020a).

Our results have important implications for policy. First, we see significant associations of the labour market shocks with financial wellbeing despite Australian active labour market programs of "JobSeeker", providing base-level support for the unemployed, and "JobKeeper", providing a firm-paid wage subsidy for those still employed at a struggling firm. Second, it is important to note that those having experienced a reduction in salary and hours worked, nonetheless experience lower levels of financial wellbeing, about equal in magnitude to those officially having lost their jobs or having applied for unemployment benefits. Thus, although the underemployed due to COVID19 are at least still "employed", their financial wellbeing is just as precarious as those explicitly unemployed due to COVID-19 lockdowns and restrictions and should therefore also be considered for policy interventions.

A bounds analysis shows that at a minimum, we cannot rule out that the estimated associations include at least partly causal effects running from a labour market shock to a reduction in financial wellbeing. In reality, it is likely that our estimated coefficients may capture both a causal effect as well as an association with unobservables. Either way, our findings point to substantial inequalities in the experience of the pandemic, be it in terms of exposure to labour market shocks by those who are "doing it tough" with very low financial wellbeing or in terms of the experienced financial wellbeing impact due to a COVID-19-related labour market shock.

This observation highlights the need for policy to target people who experienced labour market shocks during the pandemic, as these are the ones experiencing low financial wellbeing, with large inequalities due to an even stronger association between the shock and financial wellbeing at the lowest end of the financial wellbeing distribution. The fact that we find these relationships in a country such as Australia, with high incomes and living standards, a history of low unemployment and continuous growth over the last 30 years, and significant temporary government transfers during the pandemic including measures to keep employees in employment, suggests that interventions focusing on bolstering income alone might not be sufficient. Although income transfers are without question an important tool to address the immediate financial needs of people during times of hardship, they cannot reduce the uncertainty felt by individuals about the way they need to modify their living standards, spending, and wealth portfolios to adjust to the new situation and be resilient to future uncertain times. 
These pressures might be compounded by households holding large amounts of debt-Australia has one of the highest private household debt rates in the world with a household debt-to-income ratio of around 200\% according to Kearns et al. (2020). While high debt-to-income ratios are not necessarily bad, they do demand careful planning and some measure of economic stability so households can gradually pay down their debt by making regular payments or refinancing. The immense economic uncertainty, abruptly brought on by the pandemic, likely placed many households who experience labour market shocks under stress to manage their large debts and likely contributed to the low levels of financial wellbeing that we document. This uncertainty can likely only be partially offset by Australia's wage subsidies and extra COVID-19 benefit payments, since they were only intended from the outset to be temporary measures. For these households, targeted help in the form of financial counsellors or advisors as well as temporary debt relief might be appropriate measures to increase their financial wellbeing. Widespread financial counselling could in fact be offered to current welfare applicants (i.e. JobKeeper and JobSeeker) to help manage financial commitments and regain financial control during periods of economic uncertainty.

To achieve meaningful improvements in financial wellbeing, it will likely be necessary to reduce underemployment in addition to unemployment, to restore labour force participants' confidence in labour market prospects, and to buffer uncertainties with respect to financial wellbeing by a social safety net that includes financial counselling support. This is particularly important for those already very vulnerable in terms of financial wellbeing.

Acknowledgements The authors thank Tom Wilkening, Guay Lim, Cain Polidano, and Jack Rejtman for feedback on the survey, Mohamed Khalil, Ben Grauer and Andrea Nicastro for their comments on the FWBR5 scale, and the anonymous respondents recruited from Facebook and Twitter. Special thanks to Justin Wolfers, the UK Understanding Society Survey, RWI-Essen, LCC, Lynn Wilson at UofT, Sue Dynarski, Shoshana Grossbard, John Holbein, Scott Cunningham, and many others for publicising the survey at the beginning. We also thank the editor, Klaus F. Zimmermann, and four referees for very helpful comments and suggestions on a previous version of this paper.

Data availability Individuals interested in using this data should contact the corresponding author.

Compliance with ethical standards University of Melbourne (Australia) Human Research Ethics Committee (Approval ID: 2056701.1).

Conflict of interest The authors declare no conflict of interest.

Code availability Available on request. 


\section{Appendix}

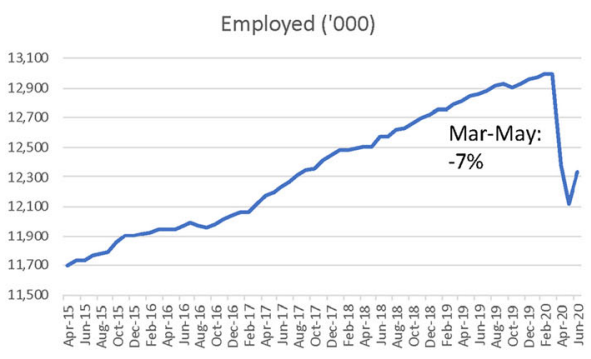

a

Unemployment rate in \%

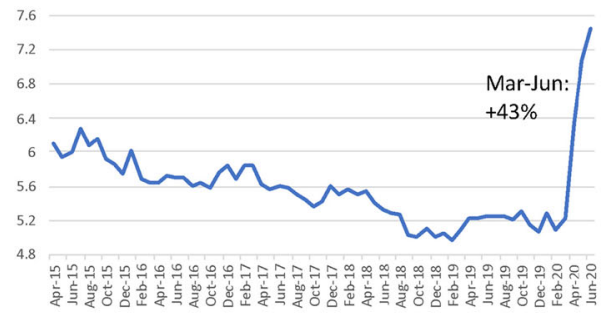

C

Monthly hours worked in all jobs

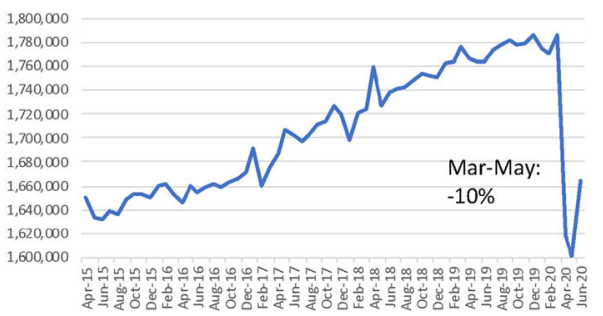

e

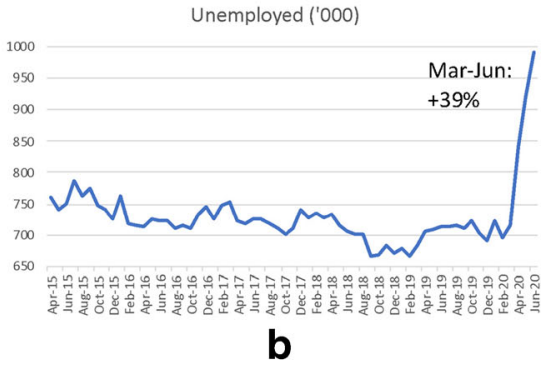

Underutilisation rate in $\%$

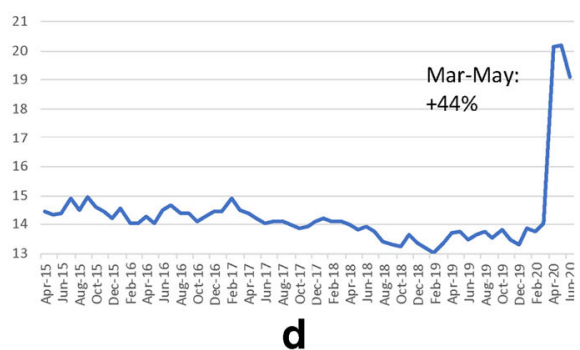

Google search: Centrelink

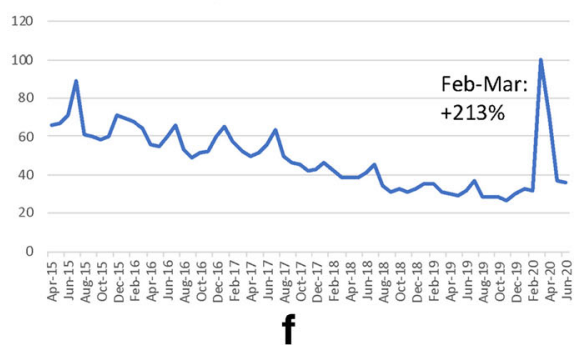

Fig. 4 Development of employment, unemployment, underutilisation rate, and online welfare searches in Australia. Note: Data from ABS Labour Force Australia Cat. No. 6202.0. Google search data from Google Trends. Fig. 4e "Monthly hours worked in all jobs" is in units of 1000's of hours 
AnyShock qß over distribution of FWB
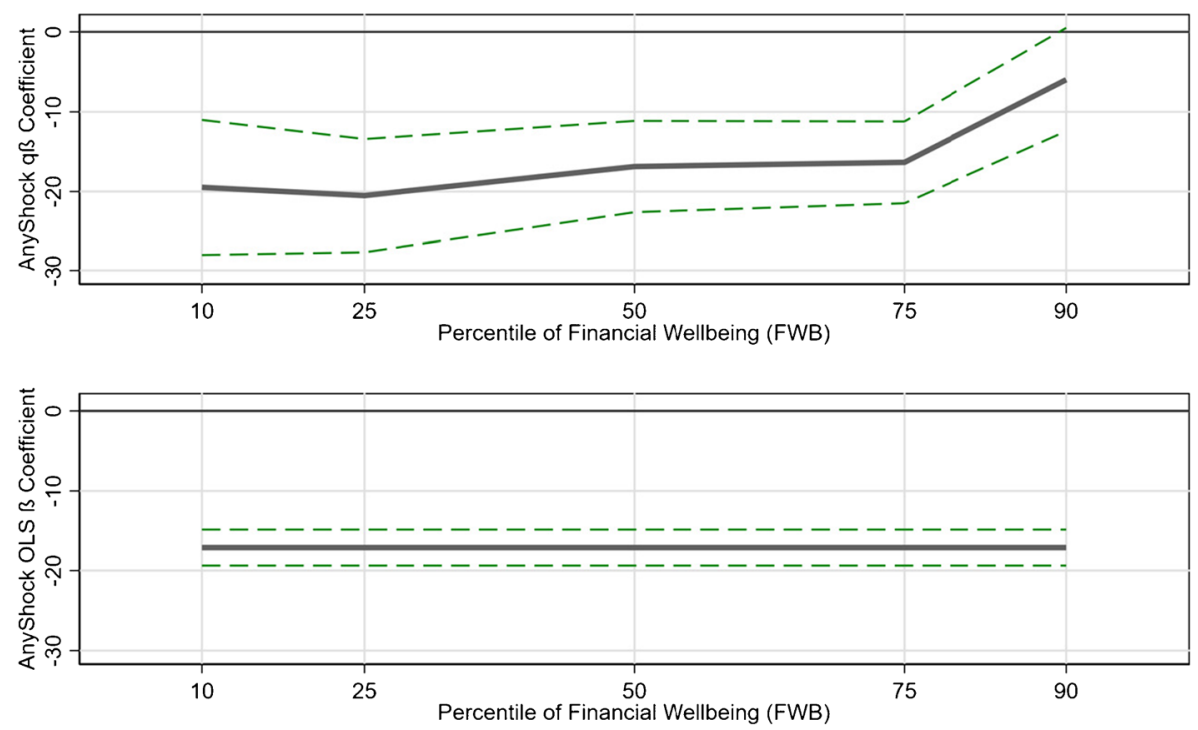

Fig. 5 Unconditional quantile regression: Coefficients over financial wellbeing distribution. Note: The top panel shows the estimated regression coefficients (Table 1, panel 1C) of the unconditional quantile regression at various percentiles $(10,25,50,75$ and 90) of the financial wellbeing distribution (black line). The point estimates are bounded in a 95\% confidence interval (green dashed lines). For the unconditional quantile estimate to be relevant, there needs to be sufficient variation in the estimated coefficients over the distribution. Traditionally, one calculates inter-percentile ranges and tests for the significance of differences between the percentiles $90-10$ or $75-25$. The bottom panel shows the average OLS coefficient $(-17.1)$ which does not change over the distribution of financial wellbeing (black line). The quantile coefficient at the 25th percentile $(-20.6)$ is larger in absolute terms than the OLS estimate $(-17.1)$ and at the 90th percentile $(-5.9)$, the estimated (insignificant) coefficient is much lower 
Table 2 Weighted, unweighted, and population-level descriptive statistics

\begin{tabular}{|c|c|c|c|c|c|}
\hline & Mean unweighted & Mean weighted & Min & Max & Mean population \\
\hline $\begin{array}{l}\text { Financial wellbeing } \\
\text { Inequality measures: } \\
\begin{array}{l}90 / 10=3.80 ; 75 / 25=2.00 \\
90 / 50=1.46 ; 10 / 50=0.39 \\
\text { Gini index }=0.234\end{array}\end{array}$ & 59.829 & 59.346 & 0 & 100 & - \\
\hline \multicolumn{6}{|l|}{ Labour market shock: } \\
\hline Reduced salary with reduced hours & 0.291 & 0.286 & 0 & 1 & - \\
\hline Unemployment or benefits & 0.240 & 0.260 & 0 & 1 & - \\
\hline Any shock & 0.349 & 0.356 & 0 & 1 & - \\
\hline Week of year & 5.617 & 4.676 & 0 & 11 & - \\
\hline Household size & 2.859 & 2.943 & 1 & 6 & 2.600 \\
\hline Male & 0.140 & 0.509 & 0 & 1 & 0.522 \\
\hline \multicolumn{6}{|l|}{ Grouped age: } \\
\hline $18-24$ & 0.069 & 0.137 & 0 & 1 & 0.164 \\
\hline $25-34$ & 0.152 & 0.258 & 0 & 1 & 0.237 \\
\hline $35-44$ & 0.249 & 0.228 & 0 & 1 & 0.225 \\
\hline $45-54$ & 0.291 & 0.201 & 0 & 1 & 0.220 \\
\hline $55-64$ & 0.239 & 0.175 & 0 & 1 & 0.154 \\
\hline \multicolumn{6}{|l|}{ Occupation: } \\
\hline Not employed & 0.084 & 0.081 & 0 & 1 & 0.070 \\
\hline Managers & 0.103 & 0.111 & 0 & 1 & 0.118 \\
\hline Professionals & 0.379 & 0.208 & 0 & 1 & 0.206 \\
\hline Trades workers & 0.033 & 0.130 & 0 & 1 & 0.127 \\
\hline Personal service & 0.082 & 0.087 & 0 & 1 & 0.102 \\
\hline Clerical & 0.108 & 0.120 & 0 & 1 & 0.126 \\
\hline Sales & 0.046 & 0.094 & 0 & 1 & 0.087 \\
\hline Machinery ops & 0.011 & 0.063 & 0 & 1 & 0.058 \\
\hline Labourers & 0.013 & 0.083 & 0 & 1 & 0.088 \\
\hline Other & 0.141 & 0.022 & 0 & 1 & 0.016 \\
\hline \multicolumn{6}{|l|}{ State: } \\
\hline Australian Capital Territory & 0.024 & 0.019 & 0 & 1 & 0.018 \\
\hline New South Wales & 0.205 & 0.308 & 0 & 1 & 0.318 \\
\hline Northern Territory & 0.008 & 0.015 & 0 & 1 & 0.011 \\
\hline Queensland & 0.131 & 0.210 & 0 & 1 & 0.198 \\
\hline South Australia & 0.060 & 0.061 & 0 & 1 & 0.067 \\
\hline Tasmania & 0.038 & 0.024 & 0 & 1 & 0.020 \\
\hline Victoria & 0.462 & 0.273 & 0 & 1 & 0.265 \\
\hline Western Australia & 0.073 & 0.091 & 0 & 1 & 0.104 \\
\hline
\end{tabular}

Note: $N=2078$. Weighted descriptive statistics are based on the gender, age, occupation, and state composition of the Australian working population ages 15-64 for the 2016 Australian Census. "Mean Population" refers to population shares for the total Australian labour force population ages 15-64 from the 2016 Census. Household size population-level data is from the 2016 Census and refers to all residents. State population shares are based on the Australian resident population in 2019 (Catalogue 31010DO002_201909). Please See ABS (2019) 
Table 3 Descriptive statistics of COVID-19 shocks by covariates

\begin{tabular}{|c|c|c|c|c|c|}
\hline & Sample share & Salary reduction & Unemploy. benefits & Any shock & Avg. FWB \\
\hline \multicolumn{6}{|l|}{ Household size: } \\
\hline 1 & $12.0 \%$ & $20.3 \%$ & $18.8 \%$ & $23.3 \%$ & 60.3 \\
\hline 2 & $33.2 \%$ & $31.0 \%$ & $26.4 \%$ & $35.8 \%$ & 58.8 \\
\hline 3 & $20.5 \%$ & $16.0 \%$ & $21.5 \%$ & $26.5 \%$ & 64.7 \\
\hline 4 & $21.9 \%$ & $34.1 \%$ & $31.9 \%$ & $42.6 \%$ & 58.7 \\
\hline 5 & $7.8 \%$ & $42.9 \%$ & $34.1 \%$ & $51.2 \%$ & 51.6 \\
\hline $6+$ & $4.7 \%$ & $37.5 \%$ & $19.1 \%$ & $47.3 \%$ & 53.4 \\
\hline \multicolumn{6}{|l|}{ Gender: } \\
\hline Female & $49.1 \%$ & $35.8 \%$ & $32.3 \%$ & $44.5 \%$ & 55.1 \\
\hline Male & $50.9 \%$ & $21.6 \%$ & $19.9 \%$ & $27.1 \%$ & 63.5 \\
\hline \multicolumn{6}{|l|}{ Age: } \\
\hline $18-24$ & $13.7 \%$ & $35.7 \%$ & $45.9 \%$ & $53.1 \%$ & 53.9 \\
\hline $25-34$ & $25.8 \%$ & $18.8 \%$ & $19.6 \%$ & $24.7 \%$ & 62.2 \\
\hline $35-44$ & $22.8 \%$ & $29.7 \%$ & $22.6 \%$ & $36.1 \%$ & 57.7 \\
\hline $45-54$ & $20.1 \%$ & $33.0 \%$ & $26.7 \%$ & $37.8 \%$ & 59.5 \\
\hline $55-64$ & $17.5 \%$ & $30.7 \%$ & $23.3 \%$ & $35.1 \%$ & 61.4 \\
\hline \multicolumn{6}{|c|}{ Unemployment status + occupation: } \\
\hline Unemployed & $8.1 \%$ & $41.1 \%$ & $59.7 \%$ & $64.0 \%$ & 41.5 \\
\hline Managers & $11.1 \%$ & $21.3 \%$ & $15.9 \%$ & $24.8 \%$ & 67.8 \\
\hline Professionals & $20.8 \%$ & $11.3 \%$ & $7.5 \%$ & $14.1 \%$ & 68.1 \\
\hline Trades workers & $13.1 \%$ & $26.6 \%$ & $11.8 \%$ & $27.0 \%$ & 62.5 \\
\hline Personal service & $8.7 \%$ & $25.1 \%$ & $21.3 \%$ & $33.4 \%$ & 59.7 \\
\hline Clerical & $12.0 \%$ & $18.1 \%$ & $15.4 \%$ & $23.9 \%$ & 60.1 \\
\hline Sales & $9.4 \%$ & $37.4 \%$ & $43.9 \%$ & $60.4 \%$ & 50.9 \\
\hline Machinery ops & $6.3 \%$ & $21.3 \%$ & $23.0 \%$ & $29.6 \%$ & 59.3 \\
\hline Labourers & $8.3 \%$ & $82.1 \%$ & $75.4 \%$ & $82.1 \%$ & 48.1 \\
\hline Not stated & $2.2 \%$ & $46.1 \%$ & $32.1 \%$ & $49.7 \%$ & 54.6 \\
\hline \multicolumn{6}{|l|}{ State: } \\
\hline ACT & $1.9 \%$ & $8.0 \%$ & $3.1 \%$ & $8.0 \%$ & 66.7 \\
\hline NSW & $30.8 \%$ & $31.5 \%$ & $30.4 \%$ & $40.1 \%$ & 58.3 \\
\hline NT & $1.5 \%$ & $35.3 \%$ & $8.8 \%$ & $35.3 \%$ & 66.1 \\
\hline QLD & $21.0 \%$ & $32.1 \%$ & $24.9 \%$ & $35.9 \%$ & 58.7 \\
\hline $\mathrm{SA}$ & $6.1 \%$ & $24.2 \%$ & $25.8 \%$ & $32.0 \%$ & 60.1 \\
\hline TAS & $2.4 \%$ & $29.1 \%$ & $32.4 \%$ & $35.5 \%$ & 54.9 \\
\hline VIC & $27.3 \%$ & $27.9 \%$ & $27.9 \%$ & $37.4 \%$ & 59.4 \\
\hline WA & $9.1 \%$ & $18.4 \%$ & $13.4 \%$ & $23.1 \%$ & 62.3 \\
\hline Total & $100.0 \%$ & $28.6 \%$ & $26.0 \%$ & $35.6 \%$ & 59.3 \\
\hline
\end{tabular}

Note: $N=2078$. Statistics are population weighted using data from the 2016 Australian Census, based on age, gender, occupation, and state 
Table 4 Financial wellbeing: any COVID-19 shocks

\begin{tabular}{|c|c|c|c|c|c|c|}
\hline & (1) & (2) & (3) & (4) & (5) & (6) \\
\hline & Mean & $\mathrm{Q}(10)$ & $Q(25)$ & $\mathrm{Q}(50)$ & $Q(75)$ & $\mathrm{Q}(90)$ \\
\hline Any shock & $\begin{array}{l}-17.110 \text { *** } \\
(2.231)\end{array}$ & $\begin{array}{l}-19.477 * * * \\
(4.318)\end{array}$ & $\begin{array}{l}-20.509 * * * \\
(3.620)\end{array}$ & $\begin{array}{l}-16.865^{* * *} \\
(2.922)\end{array}$ & $\begin{array}{l}-16.337 * * * \\
(2.620)\end{array}$ & $\begin{array}{l}-5.957 \\
(3.294)\end{array}$ \\
\hline Household size & $\begin{array}{l}0.277 \\
(0.741)\end{array}$ & $\begin{array}{l}0.365 \\
(1.429)\end{array}$ & $\begin{array}{l}0.516 \\
(1.155)\end{array}$ & $\begin{array}{l}-0.493 \\
(0.980)\end{array}$ & $\begin{array}{l}-1.142 \\
(0.982)\end{array}$ & $\begin{array}{l}-1.063 \\
(1.078)\end{array}$ \\
\hline Male & $\begin{array}{l}3.980 \\
(2.304)\end{array}$ & $\begin{array}{l}8.039^{*} \\
(3.564)\end{array}$ & $\begin{array}{l}6.236 \\
(4.060)\end{array}$ & $\begin{array}{l}4.352 \\
(3.167)\end{array}$ & $\begin{array}{l}3.725 \\
(3.331)\end{array}$ & $\begin{array}{l}4.142 \\
(3.215)\end{array}$ \\
\hline \multicolumn{7}{|l|}{ Age group: } \\
\hline $18-24$ & -- & -- & -- & -- & - & - \\
\hline $25-34$ & $\begin{array}{l}3.578 \\
(3.775)\end{array}$ & $\begin{array}{l}10.077 \\
(6.097)\end{array}$ & $\begin{array}{l}2.445 \\
(5.452)\end{array}$ & $\begin{array}{l}0.209 \\
(5.179)\end{array}$ & $\begin{array}{l}-0.442 \\
(5.178)\end{array}$ & $\begin{array}{l}1.020 \\
(5.842)\end{array}$ \\
\hline $35-44$ & $\begin{array}{l}0.411 \\
(4.012)\end{array}$ & $\begin{array}{l}2.244 \\
(6.454)\end{array}$ & $\begin{array}{l}-7.127 \\
(7.018)\end{array}$ & $\begin{array}{l}-4.563 \\
(5.254)\end{array}$ & $\begin{array}{l}4.646 \\
(5.377)\end{array}$ & $\begin{array}{l}3.007 \\
(5.706)\end{array}$ \\
\hline $45-54$ & $\begin{array}{l}3.852 \\
(3.728)\end{array}$ & $\begin{array}{l}2.038 \\
(7.113)\end{array}$ & $\begin{array}{l}-2.009 \\
(5.432)\end{array}$ & $\begin{array}{l}-0.506 \\
(4.752)\end{array}$ & $\begin{array}{l}8.093 \\
(4.723)\end{array}$ & $\begin{array}{l}3.501 \\
(5.567)\end{array}$ \\
\hline $55-64$ & $\begin{array}{l}5.080 \\
(4.397)\end{array}$ & $\begin{array}{l}7.016 \\
(6.381)\end{array}$ & $\begin{array}{l}2.442 \\
(5.488)\end{array}$ & $\begin{array}{l}-1.783 \\
(5.927)\end{array}$ & $\begin{array}{l}5.265 \\
(5.584)\end{array}$ & $\begin{array}{l}6.152 \\
(7.052)\end{array}$ \\
\hline \multicolumn{7}{|l|}{ Occupation/activity: } \\
\hline Unemployed & -- & -- & -- & -- & -- & -- \\
\hline Managers & $\begin{array}{l}20.275 * * * \\
(3.758)\end{array}$ & $\begin{array}{l}24.971 \text { *** } \\
(7.452)\end{array}$ & $\begin{array}{l}21.810^{* *} \\
(6.945)\end{array}$ & $\begin{array}{l}14.975^{* *} \\
(4.620)\end{array}$ & $\begin{array}{l}16.765 * * * \\
(4.921)\end{array}$ & $\begin{array}{l}21.401 * * * \\
(6.405)\end{array}$ \\
\hline Professionals & $\begin{array}{l}17.937 * * * \\
(3.388)\end{array}$ & $\begin{array}{l}18.481^{*} \\
(7.550)\end{array}$ & $\begin{array}{l}21.176^{* *} \\
(6.525)\end{array}$ & $\begin{array}{l}12.868 * * \\
(4.393)\end{array}$ & $\begin{array}{l}16.750 * * * \\
(4.266)\end{array}$ & $\begin{array}{l}10.346^{* *} \\
(3.525)\end{array}$ \\
\hline Trades workers & $\begin{array}{l}12.644 * * \\
(4.773)\end{array}$ & $\begin{array}{l}9.107 \\
(9.149)\end{array}$ & $\begin{array}{l}12.133 \\
(7.727)\end{array}$ & $\begin{array}{l}9.185 \\
(6.045)\end{array}$ & $\begin{array}{l}9.970 \\
(6.297)\end{array}$ & $\begin{array}{l}19.904 * * \\
(7.699)\end{array}$ \\
\hline Personal service & $\begin{array}{l}14.472 * * \\
(4.535)\end{array}$ & $\begin{array}{l}12.581 \\
(9.645)\end{array}$ & $\begin{array}{l}18.207 * \\
(7.878)\end{array}$ & $\begin{array}{l}10.600 \\
(5.430)\end{array}$ & $\begin{array}{l}14.422 * \\
(5.786)\end{array}$ & $\begin{array}{l}16.288 * \\
(6.898)\end{array}$ \\
\hline Clerical & $\begin{array}{l}12.952 * * \\
(4.008)\end{array}$ & $\begin{array}{l}20.293^{* *} \\
(7.839)\end{array}$ & $\begin{array}{l}19.235^{* *} \\
(6.465)\end{array}$ & $\begin{array}{l}12.670 * \\
(5.742)\end{array}$ & $\begin{array}{l}8.309 \\
(6.836)\end{array}$ & $\begin{array}{l}1.495 \\
(3.058)\end{array}$ \\
\hline Sales & $\begin{array}{l}8.243 \\
(4.801)\end{array}$ & $\begin{array}{l}4.850 \\
(11.277)\end{array}$ & $\begin{array}{l}6.918 \\
(8.465)\end{array}$ & $\begin{array}{l}5.337 \\
(5.815)\end{array}$ & $\begin{array}{l}3.976 \\
(5.335)\end{array}$ & $\begin{array}{l}10.075 \\
(7.140)\end{array}$ \\
\hline Machinery ops & $\begin{array}{l}11.869^{*} \\
(4.786)\end{array}$ & $\begin{array}{l}17.483 \\
(9.140)\end{array}$ & $\begin{array}{l}29.646 * * * \\
(6.861)\end{array}$ & $\begin{array}{l}9.718 \\
(8.244)\end{array}$ & $\begin{array}{l}2.595 \\
(6.819)\end{array}$ & $\begin{array}{l}-1.355 \\
(3.221)\end{array}$ \\
\hline Labourers & $\begin{array}{l}10.954 * \\
(4.467)\end{array}$ & $\begin{array}{l}36.461 * * * \\
(8.294)\end{array}$ & $\begin{array}{l}28.146 * \\
(12.371)\end{array}$ & $\begin{array}{l}2.148 \\
(6.021)\end{array}$ & $\begin{array}{l}1.594 \\
(4.590)\end{array}$ & $\begin{array}{l}2.098 \\
(2.365)\end{array}$ \\
\hline Not stated & $\begin{array}{l}10.888^{* *} \\
(3.990)\end{array}$ & $\begin{array}{l}11.932 \\
(9.035)\end{array}$ & $\begin{array}{l}16.323 * \\
(7.707)\end{array}$ & $\begin{array}{l}4.354 \\
(5.896)\end{array}$ & $\begin{array}{l}8.487 \\
(6.343)\end{array}$ & $\begin{array}{l}2.991 \\
(2.637)\end{array}$ \\
\hline \multicolumn{7}{|l|}{ State: } \\
\hline $\begin{array}{l}\text { Australian Capital } \\
\text { Territory }\end{array}$ & $\begin{array}{l}6.982 \\
(6.262)\end{array}$ & $\begin{array}{l}2.796 \\
(8.048)\end{array}$ & $\begin{array}{l}4.678 \\
(7.347)\end{array}$ & $\begin{array}{l}9.324 \\
(6.361)\end{array}$ & $\begin{array}{l}11.746 \\
(13.808)\end{array}$ & $\begin{array}{l}13.046 \\
(16.141)\end{array}$ \\
\hline New South Wales & $\begin{array}{l}0.135 \\
(4.147)\end{array}$ & $\begin{array}{l}5.603 \\
(6.715)\end{array}$ & $\begin{array}{l}5.710 \\
(4.990)\end{array}$ & $\begin{array}{l}-5.168 \\
(7.046)\end{array}$ & $\begin{array}{l}-0.917 \\
(8.129)\end{array}$ & $\begin{array}{l}-0.238 \\
(7.765)\end{array}$ \\
\hline
\end{tabular}


Table 4 (continued)

\begin{tabular}{|c|c|c|c|c|c|c|}
\hline & (1) & (2) & (3) & (4) & $(5)$ & (6) \\
\hline & Mean & $\mathrm{Q}(10)$ & $\mathrm{Q}(25)$ & $\mathrm{Q}(50)$ & $\mathrm{Q}(75)$ & $\mathrm{Q}(90)$ \\
\hline \multirow[t]{2}{*}{ Northern Territory } & $47.282 * * *$ & $47.852 * * *$ & $35.995^{*}$ & $36.453^{* *}$ & $64.281 * * *$ & $76.786^{* *}$ \\
\hline & (11.002) & $(13.090)$ & (14.858) & $(11.500)$ & (13.599) & $(28.248)$ \\
\hline \multirow[t]{2}{*}{ Queensland } & -4.757 & -3.964 & $-17.837^{*}$ & -5.165 & 0.588 & 11.106 \\
\hline & $(5.172)$ & $(6.723)$ & $(8.939)$ & $(6.960)$ & $(8.167)$ & $(9.276)$ \\
\hline \multirow[t]{2}{*}{ South Australia } & 3.450 & -0.051 & -14.628 & -1.072 & 7.774 & 11.137 \\
\hline & $(10.873)$ & $(10.037)$ & $(18.547)$ & $(12.282)$ & $(12.429)$ & $(17.047)$ \\
\hline \multirow[t]{2}{*}{ Tasmania } & -13.440 & -29.624 & -30.680 & -10.502 & 7.258 & 3.176 \\
\hline & $(12.766)$ & $(36.665)$ & $(19.745)$ & $(9.891)$ & $(9.935)$ & $(9.408)$ \\
\hline Victoria & -- & -- & -- & -- & -- & -- \\
\hline \multirow[t]{2}{*}{ Western Australia } & 0.256 & 10.768 & -0.247 & -7.658 & 3.490 & -4.625 \\
\hline & $(4.748)$ & $(6.130)$ & $(5.787)$ & (7.999) & $(9.864)$ & $(8.428)$ \\
\hline \multirow[t]{2}{*}{ Week of year } & 0.326 & 1.471 & 0.700 & -0.262 & 0.362 & -0.370 \\
\hline & $(0.482)$ & $(0.890)$ & $(0.698)$ & $(0.773)$ & $(0.628)$ & $(0.482)$ \\
\hline \multicolumn{7}{|c|}{ State $\mathrm{x}$ time trend interactions: } \\
\hline \multirow{2}{*}{$\begin{array}{l}\text { Australian Capital } \\
\text { Territory \# Week }\end{array}$} & $-2.467^{*}$ & $-3.838^{*}$ & $-3.794 *$ & -1.556 & -2.041 & -1.767 \\
\hline & $(1.256)$ & (1.914) & $(1.888)$ & $(1.367)$ & $(2.042)$ & $(2.076)$ \\
\hline \multirow{2}{*}{$\begin{array}{l}\text { New South Wales \# } \\
\text { Week }\end{array}$} & -0.053 & -1.115 & -0.714 & 0.394 & 0.552 & 0.541 \\
\hline & $(0.721)$ & $(1.241)$ & $(0.959)$ & $(1.152)$ & $(1.156)$ & $(1.067)$ \\
\hline \multirow{2}{*}{$\begin{array}{l}\text { Northern Territory \# } \\
\text { Week }\end{array}$} & $-9.080^{* * *}$ & $-8.848 * *$ & $-7.749 * * *$ & $-6.972 * *$ & $-11.489 * * *$ & $-12.707 * *$ \\
\hline & $(1.773)$ & $(3.102)$ & $(2.315)$ & $(2.361)$ & $(2.386)$ & $(4.189)$ \\
\hline \multirow[t]{2}{*}{ Queensland \# Week } & 0.729 & 0.294 & 1.353 & 0.918 & 1.090 & -0.952 \\
\hline & $(0.746)$ & $(1.028)$ & $(1.258)$ & (1.119) & $(1.325)$ & $(1.275)$ \\
\hline \multirow{2}{*}{$\begin{array}{l}\text { South Australia \# } \\
\text { Week }\end{array}$} & -0.834 & -1.844 & 1.414 & -0.051 & -0.905 & -1.018 \\
\hline & $(1.763)$ & $(1.839)$ & $(2.936)$ & $(2.135)$ & $(2.074)$ & $(2.436)$ \\
\hline \multirow[t]{2}{*}{ Tasmania \# Week } & 1.589 & 1.497 & 2.870 & 2.201 & -0.523 & 0.725 \\
\hline & $(1.788)$ & $(5.165)$ & $(2.801)$ & $(1.562)$ & $(1.410)$ & $(0.934)$ \\
\hline Victoria \# Week & -- & -- & -- & -- & -- & -- \\
\hline \multirow{2}{*}{$\begin{array}{l}\text { Western Australia \# } \\
\text { Week }\end{array}$} & -0.347 & -1.850 & -0.777 & 0.894 & -0.483 & 1.475 \\
\hline & $(0.902)$ & $(1.411)$ & $(1.306)$ & (1.294) & $(1.489)$ & $(1.463)$ \\
\hline \multirow[t]{2}{*}{ Constant } & $45.766^{* * *}$ & 2.452 & $30.574 * * *$ & $65.291 * * *$ & $68.911 * * *$ & $85.148 * * *$ \\
\hline & $(5.296)$ & $(9.980)$ & $(9.164)$ & $(7.477)$ & $(8.420)$ & $(7.535)$ \\
\hline Adj. $R^{2}$ & .223 & .130 & .165 & .163 & .154 & .099 \\
\hline
\end{tabular}

Note: $N=2078 . * p<0.05, * * p<0.01, * * * p<0.001$.

Statistics are population weighted using data from the 2016 Australian Census, based on age, gender, occupation, and state 
Table 5 Financial wellbeing: any COVID-19 shocks inter-percentile range

\begin{tabular}{|c|c|c|c|c|c|c|}
\hline & $\begin{array}{l}(1) \\
\mathrm{I}(90-10)\end{array}$ & $\begin{array}{l}(2) \\
\text { I(50-10) }\end{array}$ & $\begin{array}{l}(3) \\
\text { I(90-50) }\end{array}$ & $\begin{array}{l}\text { (4) } \\
\mathrm{I}(75-25)\end{array}$ & $\begin{array}{l}(5) \\
\text { I(50-25) }\end{array}$ & $\begin{array}{l}\text { (6) } \\
\mathrm{I}(75-50)\end{array}$ \\
\hline Any shock & $\begin{array}{l}13.520^{* *} \\
(5.084)\end{array}$ & $\begin{array}{l}2.612 \\
(4.647)\end{array}$ & $\begin{array}{l}10.907 * * \\
(3.567)\end{array}$ & $\begin{array}{l}4.172 \\
(3.837)\end{array}$ & $\begin{array}{l}3.644 \\
(3.649)\end{array}$ & $\begin{array}{l}0.528 \\
(3.038)\end{array}$ \\
\hline Household size & $\begin{array}{l}-1.427 \\
(1.710)\end{array}$ & $\begin{array}{l}-0.858 \\
(1.576)\end{array}$ & $\begin{array}{l}-0.570 \\
(1.205)\end{array}$ & $\begin{array}{l}-1.657 \\
(1.323)\end{array}$ & $\begin{array}{l}-1.009 \\
(1.192)\end{array}$ & $\begin{array}{l}-0.649 \\
(1.036)\end{array}$ \\
\hline Male & $\begin{array}{l}-3.897 \\
(4.555)\end{array}$ & $\begin{array}{l}-3.687 \\
(4.134)\end{array}$ & $\begin{array}{l}-0.210 \\
(4.015)\end{array}$ & $\begin{array}{l}-2.511 \\
(4.569)\end{array}$ & $\begin{array}{l}-1.884 \\
(4.035)\end{array}$ & $\begin{array}{l}-0.627 \\
(3.301)\end{array}$ \\
\hline \multicolumn{7}{|l|}{ Age group: } \\
\hline $18-24$ & -- & -- & -- & -- & -- & -- \\
\hline $25-34$ & $\begin{array}{l}-9.057 \\
(8.319)\end{array}$ & $\begin{array}{l}-9.869 \\
(6.987)\end{array}$ & $\begin{array}{l}0.812 \\
(7.078)\end{array}$ & $\begin{array}{l}-2.887 \\
(6.527)\end{array}$ & $\begin{array}{l}-2.236 \\
(6.157)\end{array}$ & $\begin{array}{l}-0.651 \\
(5.990)\end{array}$ \\
\hline $35-44$ & $\begin{array}{l}0.763 \\
(8.439)\end{array}$ & $\begin{array}{l}-6.806 \\
(7.285)\end{array}$ & $\begin{array}{l}7.569 \\
(6.885)\end{array}$ & $\begin{array}{l}11.773 \\
(7.571)\end{array}$ & $\begin{array}{l}2.564 \\
(6.928)\end{array}$ & $\begin{array}{l}9.209 \\
(5.408)\end{array}$ \\
\hline $45-54$ & $\begin{array}{l}1.463 \\
(8.817)\end{array}$ & $\begin{array}{l}-2.544 \\
(7.443)\end{array}$ & $\begin{array}{l}4.007 \\
(6.527)\end{array}$ & $\begin{array}{l}10.102 \\
(6.187)\end{array}$ & $\begin{array}{l}1.503 \\
(5.633)\end{array}$ & $\begin{array}{l}8.599 \\
(5.161)\end{array}$ \\
\hline $55-64$ & $\begin{array}{l}-0.863 \\
(9.157)\end{array}$ & $\begin{array}{l}-8.799 \\
(7.250)\end{array}$ & $\begin{array}{l}7.935 \\
(7.793)\end{array}$ & $\begin{array}{l}2.824 \\
(6.769)\end{array}$ & $\begin{array}{l}-4.224 \\
(6.156)\end{array}$ & $\begin{array}{l}7.048 \\
(5.945)\end{array}$ \\
\hline \multicolumn{7}{|l|}{ Occupation/activity: } \\
\hline Unemployed & -- & -- & -- & -- & -- & -- \\
\hline Managers & $\begin{array}{l}-3.570 \\
(10.137)\end{array}$ & $\begin{array}{l}-9.996 \\
(8.192)\end{array}$ & $\begin{array}{l}6.426 \\
(7.329)\end{array}$ & $\begin{array}{l}-5.045 \\
(7.826)\end{array}$ & $\begin{array}{l}-6.835 \\
(6.161)\end{array}$ & $\begin{array}{l}1.790 \\
(5.284)\end{array}$ \\
\hline Professionals & $\begin{array}{l}-8.134 \\
(8.432)\end{array}$ & $\begin{array}{l}-5.613 \\
(7.896)\end{array}$ & $\begin{array}{l}-2.521 \\
(5.078)\end{array}$ & $\begin{array}{l}-4.426 \\
(6.684)\end{array}$ & $\begin{array}{l}-8.308 \\
(5.543)\end{array}$ & $\begin{array}{l}3.882 \\
(4.434)\end{array}$ \\
\hline Trades workers & $\begin{array}{l}10.797 \\
(11.399)\end{array}$ & $\begin{array}{l}0.078 \\
(9.810)\end{array}$ & $\begin{array}{l}10.719 \\
(8.343)\end{array}$ & $\begin{array}{l}-2.163 \\
(8.456)\end{array}$ & $\begin{array}{l}-2.948 \\
(7.021)\end{array}$ & $\begin{array}{l}0.785 \\
(6.771)\end{array}$ \\
\hline Personal service & $\begin{array}{l}3.707 \\
(11.518)\end{array}$ & $\begin{array}{l}-1.981 \\
(9.357)\end{array}$ & $\begin{array}{l}5.688 \\
(7.472)\end{array}$ & $\begin{array}{l}-3.785 \\
(8.149)\end{array}$ & $\begin{array}{l}-7.607 \\
(6.702)\end{array}$ & $\begin{array}{l}3.822 \\
(5.291)\end{array}$ \\
\hline Clerical & $\begin{array}{l}-18.798^{*} \\
(8.363)\end{array}$ & $\begin{array}{l}-7.624 \\
(8.776)\end{array}$ & $\begin{array}{l}-11.174 \\
(6.361)\end{array}$ & $\begin{array}{l}-10.926 \\
(8.324)\end{array}$ & $\begin{array}{l}-6.565 \\
(6.379)\end{array}$ & $\begin{array}{l}-4.361 \\
(6.212)\end{array}$ \\
\hline Sales & $\begin{array}{l}5.224 \\
(12.897)\end{array}$ & $\begin{array}{l}0.487 \\
(10.803)\end{array}$ & $\begin{array}{l}4.737 \\
(7.617)\end{array}$ & $\begin{array}{l}-2.942 \\
(8.935)\end{array}$ & $\begin{array}{l}-1.581 \\
(7.408)\end{array}$ & $\begin{array}{l}-1.361 \\
(5.709)\end{array}$ \\
\hline Machinery ops & $\begin{array}{l}-18.839 * \\
(9.490)\end{array}$ & $\begin{array}{l}-7.765 \\
(11.794)\end{array}$ & $\begin{array}{l}-11.073 \\
(8.471)\end{array}$ & $\begin{array}{l}-27.052^{* *} \\
(9.597)\end{array}$ & $\begin{array}{l}-19.928^{*} \\
(9.339)\end{array}$ & $\begin{array}{l}-7.124 \\
(7.495)\end{array}$ \\
\hline Labourers & $\begin{array}{l}-34.363^{* * * *} \\
(8.799)\end{array}$ & $\begin{array}{l}-34.313^{* * *} \\
(9.925)\end{array}$ & $\begin{array}{l}-0.050 \\
(6.378)\end{array}$ & $\begin{array}{l}-26.552^{*} \\
(11.504)\end{array}$ & $\begin{array}{l}-25.998^{*} \\
(12.233)\end{array}$ & $\begin{array}{l}-0.554 \\
(6.529)\end{array}$ \\
\hline Not stated & $\begin{array}{l}-8.941 \\
(9.600)\end{array}$ & $\begin{array}{l}-7.578 \\
(9.795)\end{array}$ & $\begin{array}{l}-1.363 \\
(6.257)\end{array}$ & $\begin{array}{l}-7.836 \\
(8.514)\end{array}$ & $\begin{array}{l}-11.969 \\
(7.665)\end{array}$ & $\begin{array}{l}4.133 \\
(4.457)\end{array}$ \\
\hline \multicolumn{7}{|l|}{ State: } \\
\hline Australian Capital Territory & $\begin{array}{l}10.250 \\
(18.216)\end{array}$ & $\begin{array}{l}6.528 \\
(8.647)\end{array}$ & $\begin{array}{l}3.722 \\
(16.968)\end{array}$ & $\begin{array}{l}7.067 \\
(14.514)\end{array}$ & $\begin{array}{l}4.646 \\
(5.952)\end{array}$ & $\begin{array}{l}2.422 \\
(14.222)\end{array}$ \\
\hline New South Wales & $\begin{array}{l}-5.841 \\
(10.187)\end{array}$ & $\begin{array}{l}-10.771 \\
(8.917)\end{array}$ & $\begin{array}{l}4.930 \\
(10.628)\end{array}$ & $\begin{array}{l}-6.627 \\
(9.360)\end{array}$ & $\begin{array}{l}-10.878 \\
(7.371)\end{array}$ & $\begin{array}{l}4.252 \\
(9.816)\end{array}$ \\
\hline
\end{tabular}


Table 5 (continued)

\begin{tabular}{|c|c|c|c|c|c|c|}
\hline & (1) & (2) & (3) & (4) & (5) & (6) \\
\hline & $\mathrm{I}(90-10)$ & $\mathrm{I}(50-10)$ & $\mathrm{I}(90-50)$ & $\mathrm{I}(75-25)$ & $\mathrm{I}(50-25)$ & $\mathrm{I}(75-50)$ \\
\hline \multirow[t]{2}{*}{ Northern Territory } & 28.934 & -11.399 & 40.333 & $28.287 *$ & 0.459 & $27.828^{* *}$ \\
\hline & $(35.057)$ & $(19.482)$ & $(22.500)$ & $(14.357)$ & $(10.489)$ & $(9.117)$ \\
\hline \multirow[t]{2}{*}{ Queensland } & 15.070 & -1.202 & 16.271 & 18.425 & 12.672 & 5.753 \\
\hline & $(11.221)$ & (8.937) & $(10.489)$ & $(11.009)$ & $(7.492)$ & $(9.102)$ \\
\hline \multirow[t]{2}{*}{ South Australia } & 11.189 & -1.020 & 12.209 & 22.402 & 13.557 & 8.845 \\
\hline & $(19.240)$ & (12.993) & $(16.240)$ & $(14.580)$ & $(9.414)$ & $(10.609)$ \\
\hline \multirow[t]{2}{*}{ Tasmania } & 32.801 & 19.122 & 13.679 & $37.938 *$ & 20.178 & $17.761^{*}$ \\
\hline & $(37.684)$ & $(31.589)$ & (13.130) & $(17.926)$ & (14.718) & $(8.142)$ \\
\hline Victoria & -- & -- & -- & -- & -- & -- \\
\hline \multirow[t]{2}{*}{ Western Australia } & -15.393 & $-18.426^{*}$ & 3.033 & 3.738 & -7.411 & 11.149 \\
\hline & $(10.306)$ & $(9.133)$ & $(9.908)$ & $(11.111)$ & $(8.523)$ & $(8.208)$ \\
\hline \multirow[t]{2}{*}{ Week of year } & -1.841 & -1.732 & -0.109 & -0.338 & -0.962 & 0.624 \\
\hline & $(0.978)$ & $(0.906)$ & $(0.841)$ & $(0.914)$ & $(0.741)$ & $(0.885)$ \\
\hline \multicolumn{7}{|l|}{ State $\mathrm{x}$ time trend interactions: } \\
\hline \multirow{2}{*}{$\begin{array}{l}\text { Australian Capital Territory \# } \\
\text { Week }\end{array}$} & 2.071 & 2.282 & -0.211 & 1.753 & 2.238 & -0.486 \\
\hline & $(2.904)$ & $(2.021)$ & $(2.408)$ & $(2.106)$ & $(1.165)$ & $(1.870)$ \\
\hline \multirow[t]{2}{*}{ New South Wales \# Week } & 1.655 & 1.508 & 0.147 & 1.266 & 1.108 & 0.158 \\
\hline & (1.599) & $(1.460)$ & $(1.532)$ & $(1.446)$ & $(1.207)$ & $(1.417)$ \\
\hline \multirow[t]{2}{*}{ Northern Territory \# Week } & -3.859 & 1.876 & -5.735 & -3.740 & 0.777 & $-4.517^{*}$ \\
\hline & $(6.224)$ & $(4.333)$ & $(3.403)$ & $(3.203)$ & $(2.633)$ & $(1.921)$ \\
\hline \multirow[t]{2}{*}{ Queensland \# Week } & -1.246 & 0.624 & -1.870 & -0.263 & -0.435 & 0.172 \\
\hline & $(1.544)$ & $(1.352)$ & (1.649) & (1.843) & $(1.201)$ & $(1.500)$ \\
\hline \multirow[t]{2}{*}{ South Australia \# Week } & 0.826 & 1.793 & -0.967 & -2.319 & -1.465 & -0.854 \\
\hline & $(3.014)$ & $(2.195)$ & $(2.626)$ & $(2.360)$ & $(1.677)$ & $(1.853)$ \\
\hline \multirow[t]{2}{*}{ Tasmania \# Week } & -0.772 & 0.704 & -1.476 & -3.393 & -0.669 & -2.724 \\
\hline & $(5.233)$ & $(4.541)$ & $(1.893)$ & $(2.616)$ & $(2.256)$ & $(1.665)$ \\
\hline Victoria \# Week & -- & -- & -- & -- & -- & -- \\
\hline \multirow[t]{2}{*}{ Western Australia \# Week } & 3.324 & 2.744 & 0.580 & 0.294 & 1.672 & -1.377 \\
\hline & $(1.950)$ & $(1.654)$ & $(1.628)$ & (1.803) & $(1.425)$ & $(1.333)$ \\
\hline \multirow[t]{2}{*}{ Constant } & $82.697 * * *$ & $62.839 * * *$ & $19.857^{*}$ & $38.337 * * *$ & $34.716^{* * * *}$ & 3.620 \\
\hline & $(12.589)$ & $(11.602)$ & $(9.679)$ & (11.278) & $(9.535)$ & $(9.828)$ \\
\hline Adj. $R^{2}$ & .087 & .054 & .070 & .099 & .080 & .055 \\
\hline
\end{tabular}

Note: $N=2078 . * p<0.05, * * p<0.01, * * * p<0.001$

Statistics are population weighted using data from the 2016 Australian Census, based on age, gender, occupation, and state 


\section{References}

Alesina A, Harnoss J, Rapoport H (2016) Birthplace diversity and economic prosperity. J Econ Growth 21(2): 101-138

Ali SH, Foreman J, Capasso A, Jones AM, Tozan Y, DiClemente RJ (2020) Social media as a recruitment platform for a nationwide online survey of COVID-19 knowledge, beliefs, and practices in the United States: methodology and feasibility analysis. BMC Med Res Methodol 20:116

Altonji JG, Elder TE, Taber CR (2005) Selection on observed and unobserved variables: assessing the effectiveness of Catholic schools. J Polit Econ 113(1):151-184

Antoun C, Zhang C, Conrad FG, Schober MF (2016) Comparisons of online recruitment strategies for convenience samples: Craigslist, Google AdWords, Facebook, and Amazon Mechanical Turk. Field Methods 28(3):231-246

Australian Bureau of Statistics (ABS) (2019) Australian Demographic Statistics, September 2019, Release 3101.0. Australian Bureau of Statistics, Canberra

Belot M, Choi S, Tripodi E, van den Broek-Altenburg E, Jamison JC, Papageorge NW (2020) Unequal consequences of COVID-19 across age and income: representative evidence from six countries. IZA Discussion Paper No. 13366, Bonn, Institute of Labor Economics

Biddle N, Edwards B, Gray M, Sollis K (2020a) Hardship, distress, and resilience: the initial impacts of COVID-19 in Australia. COVID-19 Briefing Paper, ANU Centre for Social Research and Methods, Australian National University, Canberra

Biddle N, Edwards B, Gray M, Sollis K (2020b) Tracking outcomes during the COVID-19 pandemic (August 2020) - divergence within Australia. COVID-19 Briefing Paper, ANU Centre for Social Research and Methods, Australian National University, Canberra

Bonacini L, Gallo G, Patriarca F (2021) Identifying policy challenges of COVID-19 in hardly reliable data and judging the success of lockdown measures. J Popul Econ 34:275-301

Bond TN, Lang K (2019) The sad truth about happiness scales. J Polit Econ 127(4):1629-1640

Bonke J, Browning M (2009) The distribution of financial well-being and income within the household. Rev Econ Househ 7(1):31-42

Botha F, de New JP, de New SC, Ribar DC, Salamanca N (2020a) COVID-19 labour market shocks and their inequality implications for financial wellbeing, GLO Discussion Paper, No. 661, Global Labor Organization (GLO), Essen

Botha F, de New JP, Nicastro A (2020b) Developing a short form version of the Commonwealth BankMelbourne Institute Reported Financial Well-being Scale. Commonwealth Bank of Australia and Melbourne Institute Financial Well-being Scales Technical Report No. 5. Melbourne: University of Melbourne

Botha F, de New JP (2020) COVID-19 infections, labour market shocks, and subjective well-being. Melbourne Institute Working Paper No. 14/20, University of Melbourne

Brenner L, Meyll T, Stolper O, Walter A (2020) Consumer fraud victimization and financial well-being. J Econ Psychol 76:102243

Brodeur A, Clark AE, Flèche S, Powdthavee N (2020) COVID-19, lockdowns and well-being: Evidence from Google Trends. IZA Discussion Paper No. 13204, Bonn, Institute of Labor Economics

Brown S, Gray D (2016) Household finances and well-being in Australia: an empirical analysis of comparison effects. J Econ Psychol 53:17-36

Chernozhukov V, Fernández-Val I, Melly B (2013) Inference on counterfactual distributions. Econometrica 81(6):2205-2268

Chernozhukov V, Fernández-Val I, Melly B (2020a) Quantile and distribution regression in Stata: algorithms, pointwise and functional inference. Unpublished paper

Chernozhukov V, Fernández-Val I, Melly B, Wüthrich K (2020b) Generic inference on quantile and quantile effect functions for discrete outcomes. J Am Stat Assoc 115(529):123-137

Comerton-Forde C, Ip E, Ribar DC, Ross J, Salamanca N, Tsiaplias S (2018) Using survey and banking data to measure financial well-being. Commonwealth Bank of Australia and Melbourne Institute Financial Well-being Scales Technical Report No. 1. Melbourne: University of Melbourne

Comerton-Forde C, de New JP, Salamanca N, Ribar DC, Nicastro A, Ross J (2020) Measuring financial wellbeing with self-reported and bank-record data. Melbourne Institute Working Paper No. 26/20, University of Melbourne

Consumer Financial Protection Bureau (2017) CFPB financial well-being scale: scale development technical report. CFPB, Washington, DC 
DiNardo J, Fortin N, Lemieux T (1996) Labor market institutions and the distribution of wages, 1973-1992: a semiparametric approach. Econometrica 64:1001-1044

Fetzer T, Hensel L, Hermle J, Roth C (2020) Coronavirus perceptions and economic anxiety. Review of Economics and Statistics, https://doi.org/10.1162/rest_a_00946

Firpo S, Fortin NM, Lemieux T (2009) Unconditional quantile regressions. Econometrica 77(3):953-973

French D (2018) Financial strain in the United Kingdom. Oxf Econ Pap 70(1):163-182

Grewenig E, Lergetporer P, Simon L, Werner K, Woessmann L (2018) Can online surveys represent the entire population? IZA Discussion Paper No. 11799

Haisken-DeNew JP, Ribar DC, Salamanca N, Nicastro A (2018) Using survey and banking data to understand Australians' financial wellbeing. Commonwealth Bank of Australia and Melbourne Institute Financial Wellbeing Scales Technical Report No 2

Hanushek EA, Schwerdt G, Woessmann L, Zhang L (2017) General education, vocational education, and labor-market outcomes over the lifecycle. J Hum Resour 52(1):48-87

Jenkins SP (1999) INEQDEC0: Stata module to calculate inequality indices with decomposition by subgroup. Statistical Software Components S366007, Boston College Department of Economics, revised 22 Jan 2015

Kearns J, Major M, Norman D (2020) How risky is Australian household debt, Reserve Bank of Australia Research Paper RDP 2020-05, Reserve Bank of Australia

Mian A, Sufi A (2014) What explains the 2007-2009 drop in employment? Econometrica 82(6):2197-2223

Milani F (2021) COVID-19 outbreak, social response, and early economic effects: a global VAR analysis of cross-country interdependencies. J Popul Econ 34:223-252

Muir K, Hamilton M, Noone JH, Marjolin A, Salignac F, Saunders P (2017) Exploring financial wellbeing in the Australian context. Report for financial literacy Australia. Centre for Social Impact \& Social Policy Research Centre, University of New South Wales, Sydney

Netemeyer RG, Warmath D, Fernandes D, Lynch JG (2018) How am I doing? Perceived financial well-being, its potential antecedents, and its relation to overall well-being. J Consum Res 45:68-89

Oster E (2019) Unobservable selection and coefficient stability: theory and evidence. J Bus Econ Stat 37(2): 187-204

Oster, E (2013) PSACALC: stata module to calculate treatment effects and relative degree of selection under proportional selection of observables and unobservables, Statistical Software Components S457677, Boston College Department of Economics, revised 18 Dec 2016

Qiu Y, Chen X, Shi W (2020) Impacts of social and economic factors on the transmission of coronavirus disease 2019 (COVID-19) in China. J Popul Econ 33(4):1127-1172

Rios-Avila F (2020) Recentered influence functions (RIFs) in Stata: RIF regression and RIF decomposition. Stata J 20(1):51-94

Riphahn RT, Serfling O (2005) Item non-response on income and wealth questions. Empir Econ 30(2):521538

Schmeiser M, Seligman J (2013) Using the right yardstick: assessing financial literacy measures by way of financial well-being. J Consum Aff 47(2):243-262

Scutella R, Wooden M (2004) Jobless households in Australia: incidence, characteristics and financial consequences. Econ Labour Relat Rev 14(2):187-207

Shim S, Xiao J, Barber B, Lyons A (2009) Pathways to life success: a conceptual model of financial wellbeing for young adults. J Appl Dev Psychol 30(6):708-723

Simona-Moussa J, Ravazzini L (2019) From one recession to another: longitudinal impacts on the quality of life of vulnerable groups. Soc Indic Res 142:1129-1152

Van Kerm P (2015) Modelling income distributions: 'distribution regression approaches' and related methods. Luxembourg Institute of Socio-Economic Research, InGRID Summer School on 'Advanced poverty research: poverty and material deprivation dynamics', Esch-sur-Alzette, Belval campus, 6-10 July 2015, mimeo

Vlaev I, Elliott A (2014) Financial well-being components. Social Indicators Research 118(3):1103-1123

World Bank (2020) Global economic prospects, June 2020. Washington, DC: World Bank https://doi.org/10. 1596/978-1-4648-1553-9

Publisher's note Springer Nature remains neutral with regard to jurisdictional claims in published maps and institutional affiliations. 


\section{Affiliations}

\section{Ferdi Botha $^{1,2}$ - John P. de New ${ }^{1,2,3} \cdot$ Sonja C. de New ${ }^{2,4,5,6}$ - David C. Ribar ${ }^{1,6,7}$. Nicolás Salamanca ${ }^{1,2,6}$}

1 Melbourne Institute: Applied Economic \& Social Research, University of Melbourne, 111 Barry Street, Carlton, VIC 3053, Australia

2 ARC Centre of Excellence for Children and Families over the Life Course, Indooroopilly, Australia

3 Global Labor Organization (GLO), Bonn, Germany

4 Centre for Health Economics, Monash University, Melbourne, Australia

5 RWI Research Network, Essen, Germany

6 Institute of Labor Economics (IZA), Bonn, Germany

7 Department of Economics, Georgia State University, Atlanta, USA 